\title{
Crustal structure between the Knipovich Ridge and the Van Mijenfjorden (Svalbard)
}

\author{
Oliver Ritzmann ${ }^{1, *}$, Wilfried Jokat ${ }^{2}$, Rolf Mjelde ${ }^{1}$ and Hideki Shimamura ${ }^{3}$ \\ ${ }^{1}$ Institut for Geologi, Postboks 1047, Blindern, N-0316, Olso, Norway; ${ }^{2}$ Alfred Wegener Institute for Polar \\ and Marine Research, Bremerhaven, Germany; ${ }^{3}$ Institute of Seismology and Volcanology, Hokkaido Univer- \\ sity, Sapporo, Japan; *Author for correspondence (Tel: ++47 5558 26 49; Fax: ++47 555896 69; E-mail: \\ oliver.ritzmann@geo.uib.no
}

\begin{abstract}
The Alfred Wegener Institute of Polar and Marine Research, the University of Bergen and Hokkaido University acquired new seismic refraction data along a transect from the Knipovich Ridge to the inner Van Mijenfjorden in southern Svalbard. A close spacing of on- and offshore receivers and a dense marine shot pattern provide the data for a high resolution p-wave velocity model for geological interpretation. Additional new seismic reflection data (University of Bergen) yield structural information for a more reliable analysis. Crustal thickness along the Van Mijenfjorden is 33 to $34 \mathrm{~km}$. Seismic velocities of $5.0 \mathrm{~km} \mathrm{~s}^{-1}$ are observed within the upper crustal section of the Tertiary Central Spitsbergen Basin. A Paleozoic sedimentary basin with a depth of 8 to $10 \mathrm{~km}$ is associated with the Nordfjorden Block. The seismic velocities are up to $6.0 \mathrm{~km} \mathrm{~s}^{-1}$. Paleozoic sedimentary rocks are expected further to the west of the Hornsund Lineament since seismic velocities reveal a similar range here. West of the Bellsund the continental crust thins gradually over a $90 \mathrm{~km}$ wide rifted zone. The velocity structure within this section is very complex and comprises zones of decreased velocities below the West Spitsbergen Fold Belt (down to $20 \mathrm{~km}$ depth) and slightly elevated velocities $\left(7.2 \mathrm{~km} \mathrm{~s}^{-1}\right)$ at the crust-mantle transition. The first structure is interpreted as intensively fractured rocks linked to post-Late Paleocene transpressive orogenic activity and subsequently affected by transtension during break-up from Greenland. The faster deep-crustal velocities are supposed to express magmatic intrusions of an unidentified origin. Melts could either be channelled by the Spitsbergen Shear Zone from more distant sources, or originate in the magmatic interaction between the northern Knipovich Ridge and the neighbouring young rifted crust. Oceanic crust each side of the Knipovich Ridge is thin $(\sim 3.5 \mathrm{~km})$ and is characterised by the absence of oceanic layer 3 (3.5/4.1 to $\left.4.7 \mathrm{~km} \mathrm{~s}^{-1}\right)$. The oceanic section exhibits zones of very thin crust $(\sim 1 \mathrm{~km})$ that are interpreted as fracture zones. Beneath these we observed decreased mantle velocities $\left(\sim 7.3 \mathrm{~km} \mathrm{~s}^{-1}\right)$ indicating probable serpentinization of peridotites along these fracture zones. Thickness variations further provide information about the segmentation and magma supply along the northern Knipovich Ridge.
\end{abstract}

\section{Introduction}

The crustal structure of the interior of the Svalbard Archipelago, its western continental margin, the neighbouring oceanic province and the Knipovich Ridge have been investigated by Guterch et al. (1978), Sellevoll et al. (1991), Myhre and Eldholm (1988) and Faleide et al. (1991). In these studies the lateral resolution of velocities in the seismic refraction data is too limited to provide a detailed image across the continental margin of western Svalbard. Due to this, detailed knowledge about Svalbard's crustal structure and evolution is rather limited.

In 1997 the Alfred Wegener Institute of Polar and Marine Research (Germany) carried out a seismic re- fraction experiment in the region of the Knipovich Ridge, Bellsund and Van Mijenfjorden (AWI-97260; Jokat et al., 1998). A close spacing of on- and offshore receivers and a dense shot pattern yield the detailed velocity structure of Svalbard's Caledonian terrane configuration (Harland and Wright, 1979), the West Spitsbergen Fold Belt (Steel et al., 1985) as well as the continent-ocean boundary along the Hornsund Lineament (Myhre and Eldholm, 1988; Eiken and Austegard, 1987).

During the OBS98 survey by the University of Bergen (Norway) and Hokkaido University (Japan) this profile was extended along the Knipovich Ridge in order to provide a complete transect for further analysis of possible interaction between the mid-ocean 
ridge and young rifted crust during break-up (profile 9 , Mjelde et al., 1998). The data base was completed by the acquisition of seismic reflection data by the University of Bergen in 1999 on a parallel line across the oceanic crustal section and the outer continent-ocean transition (profile 7; Mjelde and Johansen, 1999). Airborne gravity data of (Boebel, 2000) is used to further constrain the interpretation of newly derived seismic data.

\section{Geological and geophysical setting}

The Svalbard Archipelago is situated at the northwestern corner of the Eurasian continent and is separated from northeastern Greenland by the Fram Strait (Figure 1). Svalbard itself has been suggested to consist of three basement terranes that amalgamated in the Devonian. These terranes are bounded by sinistral transform faults, the Kongsfjorden-Hansbreen Fault Zone and Billefjorden Fault Zone (Harland and Wright, 1979; Figure 1). A rival interpretation insists that Svalbard is built up of a unique basement province (Manby and Lyberis, 1992). Northern Svalbard is partly covered by Devonian sedimentary rocks (Figure 1) that dip below the Late Paleozoic/Mesozoic and Cenozoic cover in southern Svalbard (Nordfjorden Block, Isfjorden; Johannessen and Steel, 1992; Nøttvedt et al., 1993). The western coastal province south of Kongsfjorden mainly comprises the West Spitsbergen Fold Belt which formed during late Paleocene to Mid-Eocene transpression (Steel et al., 1985; Harland, 1997c). Sediments derived from the orogen accumulated on either side of the belt and are preserved onshore in the Tertiary Central Spitsbergen Basin (Harland, 1997c) and offshore as shown by seismic reflection surveys (Schlüter and Hinz, 1978). During the early, mainly transpressive movements of the orogeny elongated basins such as the Forlandsundet Graben (Gabrielsen et al., 1992) and the Bellsund Graben (Eiken and Austegard, 1987) subsided in the centre of the belt. Both resemble pull-apart structures, but their exact geological history is still under debate (Steel et al. 1985; Harland, 1997c).

After the initial opening of the NorwegianGreenland Sea in the Early Paleocene the mid-oceanic ridge system propagated northward along the Spitsbergen Shear Zone, forming the Knipovich Ridge (Eldholm et al. 1987; Crane et al., 1991). Since the Mid-Oligocene transpressive movements dominated along the western Svalbard margin and the Horn- sund Lineament is supposed to have been the active fault system between Svalbard and Greenland (Eldholm et al., 1987; Eiken, 1993). Spreading along the Knipovich Ridge is slow (0.8 cm/a, half rate) and possibly extremely asymmetric: favouring accretion to the eastern flank (Eldholm et al., 1990; Crane et al., 1991). Recent structural mapping of the Fram Strait using airborne gravity data and subsequent plate tectonic modelling of Boebel (2000) assume the onset of spreading at Molloy Ridge occurred in the Early Miocene. Further north within the Fram Strait spreading started in the Early Pliocene.

\section{Previous deep seismic investigations}

Deep seismic investigations of the Svalbard Archipelago started in 1976 (Guterch, 1978; Sellevoll et al., 1991). All experiments are characterised by few onshore seismic receivers and a widely spaced $(\sim 10 \mathrm{~km})$ offshore shot pattern. Unfortunately, these experiments were not able to resolve a detailed lateral velocity structure. Similar data were acquired on later surveys (Sellevoll et al., 1991; Czuba et al., 1999) and further expanding spread profiles were carried out (Myhre and Eldholm, 1988; Faleide et al., 1991).

A crustal thickness of $\sim 36 \mathrm{~km}$ is estimated below central Svalbard (Sellevoll et al., 1991). A seismic transect from Storfjorden and Van Mijenfjorden to Isfjorden (Figure 1) indicates a $\sim 3 \mathrm{~km}$ thick transitional layer above the Moho $\left(7.8 \mathrm{~km} \mathrm{~s}^{-1}\right)$. Crustal thickness decreases towards the outer fjords to $26-27 \mathrm{~km}$ (Forlandsundet) where stretched continental crust is predicted. This was recently confirmed by Ritzmann and Jokat (2003). The continent-ocean boundary off western Svalbard is determined by seismic reflection profiles only (Hornsund Lineament; Myhre and Eldholm, 1988; Eiken, 1994). Additional constraints on the crustal structure off Isfjorden are given by gravity modelling (Myhre and Eldholm, 1988; Sundvor and Austegard, 1990), which generally confirms the continental crustal character of western Svalbard.

Petrological constraints on the crustal composition of Svalbard come from mantle derived xenoliths found in the Woodfjorden (Amundsen et al., 1987; Figure 1) that reveal a good correlation to the simple velocity structure published by Chan and Mitchell (1982). The northern central terrane (Harland and Wright, 1979) consists of a gneissic structure $(\sim 6.2 \mathrm{~km}$ $\mathrm{s}^{-1}$ ) down to $16 \mathrm{~km}$ depth that is partly overlaid by Paleozoic/Mesozoic sedimentary/metasedimentary 


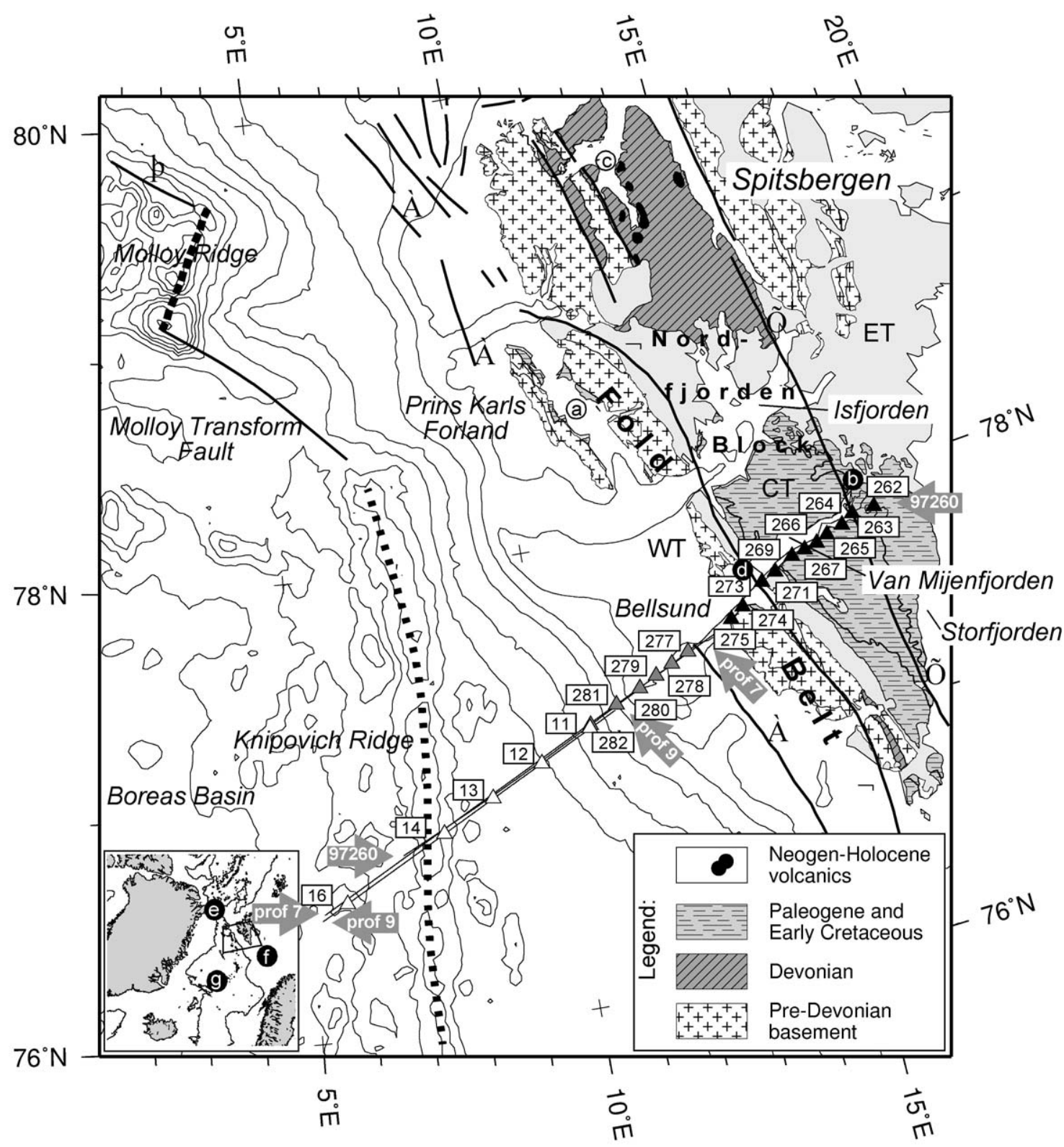

Figure 1. Location of seismic refraction profile AWI-97260, profile 9 (obs98-survey) and seismic reflection profile 7. Gray thick arrows mark the western and eastern start and end of the profiles. The profile tracks are marked by thin black lines, RefTek-stations (black), OBH-stations (gray) and obs-stations (white) by triangles with the respective station numbers in squares. Simplified geology after Harland (1997a). Thick black lines are major faults: (1) Spitsbergen Transform Fault, (2) Hornsund Lineament, (3) Kongsfjorden-Hansbreen Fault Zone, (4) Billefjorden Fault Zone. Spreading ridges are marked by a thick dotted line. Geographic locations used in the text: (a) Forlandsundet, (b) Heer Land, (c) Woodfjorden, (d) Akseløya, (e) Fram Strait, (f) Barents Sea, (g) Mohns Ridge. Western-, central- and eastern terrane (WT, CT and ET). Plate boundary after Boebel (2000). Bathymetry: IBCAO (500 m-contour interval + 200 m-contour; Jakobsson et al., 2000). 
a)
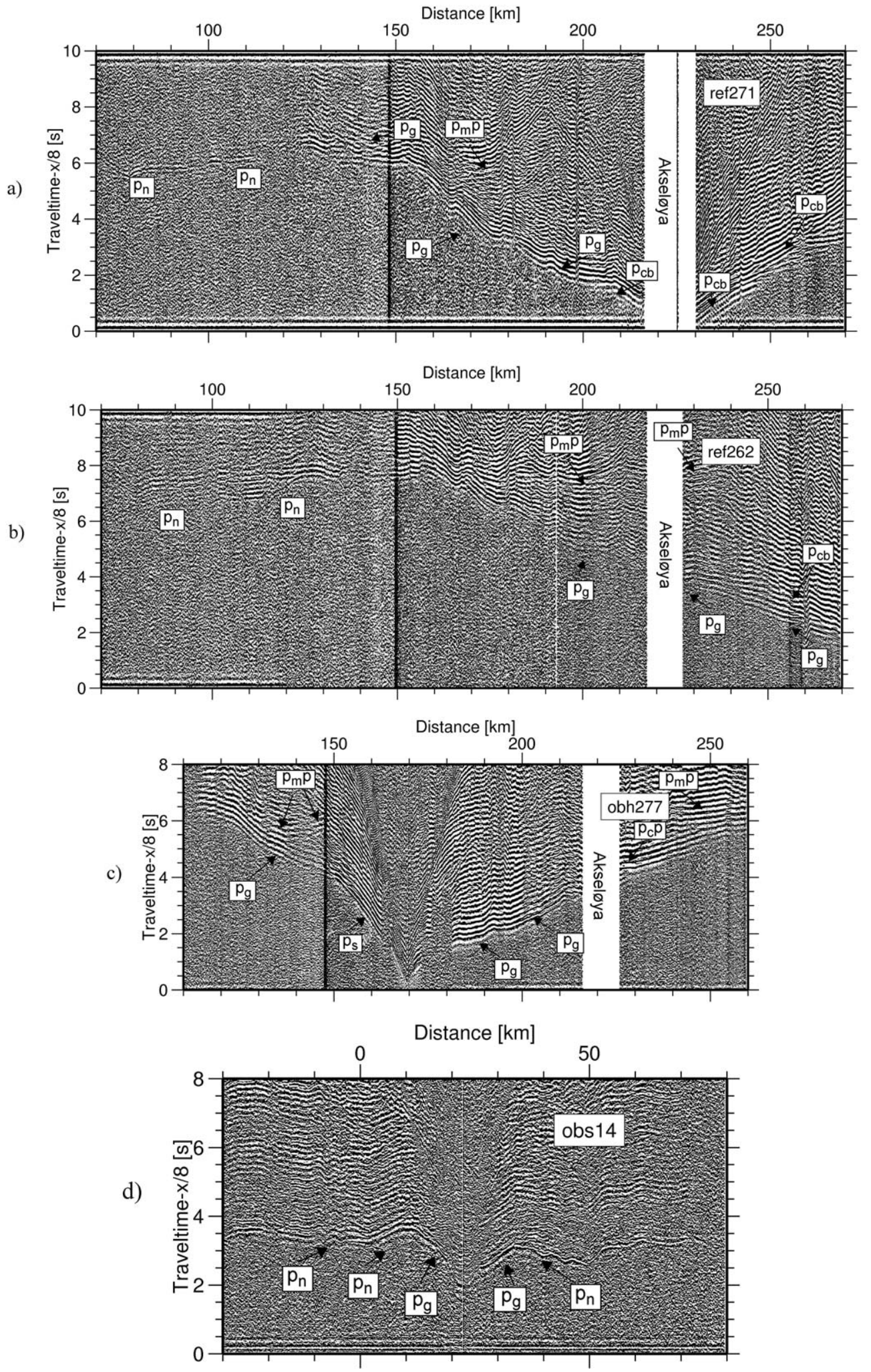

Figure 2. a-d. Data Examples - ref271, obh277 and obs14. Record sections of station ref271, ref262, obh277 and obs14. A bandpass filter passing frequencies from $5-17 \mathrm{~Hz}$ was applied to the data and a $1 \mathrm{~s}$-automatic gain control. Stations obs 14 is further processed by predictive deconvolution (see text). 
rocks. The mafic granulites below $\left(\sim 6.4 \mathrm{~km} \mathrm{~s}^{-1}\right)$ are supposed to be intruded by mantle derived lherzolites within the lower $5 \mathrm{~km}\left(6.8 \mathrm{~km} \mathrm{~s}^{-1}\right.$; Amundsen et al., 1987).

\section{New geophysical data}

The data along the deep seismic transect off Van Mijenfjorden were collected during three cruises of the research vessels RV Polarstern (Germany) and RV Håkon Mosby (Norway) in 1997, 1998 and 1999 (Jokat et al., 1998; Mjelde et al., 1998; Mjelde and Johansen, 1999).

\section{Seismic refraction data - acquisition}

Seismic refraction data was acquired during the cruise leg ARK13/3 of RV Polarstern (profile AWI-97260) using seven offshore ocean-bottom hydrophone $(\mathrm{OBH})$ systems (one failed; $13.3^{\circ} \mathrm{E}-$ $\left.10.8^{\circ} \mathrm{E}\right)$ and 15 onshore RefTek seismometer stations $\left(14.0^{\circ} \mathrm{E}-17.3^{\circ} \mathrm{E}\right)$. Each of the onshore receivers was equipped with an array of at least 18 geophones (vertical component registrations). Eight of the RefTek seismometer stations were connected to a geophone array $\sim 500 \mathrm{~m}$ away from the main station. Thus, in total 23 record sections from the onshore stations were achieved. A total number of 1595 shots used an array of three large-volume airguns with a total charge of 1521 (Figure 1; $6.8^{\circ} \mathrm{E}-16.7^{\circ} \mathrm{E}$ ). The shot track extends from the valley of the Knipovich Ridge to the eastern part of the Van Mijenfjorden. Velocity modelling for this study was performed using data from all offshore stations and a selection of 11 stations onshore, so that the receiver spacing varies from 10-16 km (offshore) and from 6-15 km (onshore).

Profile AWI-97260 was extended in 1998 during cruise OBS-98 of RV Håkon Mosby (profile 9; Figure 1) using six ocean-bottom seismometer devices (one failed; 3-component; 5.5 E-10.7 ${ }^{\circ}$ E). Profile 9 comprises 873 shots fired from $5.2^{\circ} \mathrm{E}-11.3^{\circ} \mathrm{E}$ using a four-airgun array with a total charge of $\sim 791$. The receiver spacing is $\sim 30 \mathrm{~km}$ along profile 9 with one larger gap of $50 \mathrm{~km}$. The overall length of seismic refraction transects AWI-97260 and profile 9 is about $360 \mathrm{~km}$ extending from the southeastern Boreas Basin to western Heer Land in southern Svalbard (Figure 1). Elevation varies along the profiles from $-3250 \mathrm{~m}$ to $700 \mathrm{~m}$.
Seismic refraction data - Processing and characteristics

Prior to analysis seismic refraction data was processed with a bandpass filter passing frequencies of 5 to $17 \mathrm{~Hz}$. A better amplitude equalisation of large offset arrivals was reached using a 1 s-automatic gain control (agc). Generally, onshore seismic data within the Van Mijenfjorden is characterised by strong amplitude reverberations, most likely due to shortwavelength water column multiples on a glacial compacted seafloor (Figures 2a and b). Noise is further expected from strong side-reflections within the fjord and peg-leg type travelpaths within the sedimentary section (Posewang and Mienert, 1999). Along profile 9 signal enhancement by predictive deconvolution of ocean bottom seismometer (OBS)-data was performed. Here, the wave train is also characterised by strong multiples/reverberations running parallel to the first arrivals (Figure 3a). The operator length was set to $170 \mathrm{~ms}$, and a gap length of $10 \mathrm{~ms}$ was determined to give best results. The filter operation was applied to the entire trace lengths. Figure $3 \mathrm{~b}$ clearly indicates the advantage of the applied deconvolution, i.e., later secondary arrivals are better seen on the seismic sections. Hence, velocity gradients are calculated more precisely. The abbreviation must be defined and capitalized OBS-recordings provide mainly first arrival velocity information and sparse information from secondary arrivals. According to the modified shape of the seismic signals a larger uncertainty was assigned to secondary arrival times picked from deconvolved seismic sections.

Figures $2 \mathrm{a}$ and $\mathrm{b}$ show the recordings of the stations ref271 and ref262 (located approximately $16 \mathrm{~km}$ east of Akseløya and at the eastern end of the profile). These sections are representative of the continental profile section along the Van Mijenfjorden. At near offsets the first arrivals are diving p-waves through the Cretaceous to Cenozoic cover of Svalbard's Central Basin (Figure 2a; $\mathrm{p}_{\mathrm{cb}}$ ). Further east these become secondary arrivals (Figure $2 b$ ) since refracted energy from the deeper basement was recorded as first arrivals at these distances. West of Akseløya at $200 \mathrm{~km}$ seismic velocities increase apparently at the Kongsfjorden-Hansbreen Fault Zone ( $\left.\mathrm{p}_{\mathrm{g}}\right)$. Seismic velocities of $\mathrm{p}_{\mathrm{g}}$-phases decrease again in the westerly direction, where traveltimes are delayed due to the thickening of the Cenozoic sedimentary cover of the shelf region (Figures $2 \mathrm{a}$ and $\mathrm{b}$ ). At $150 \mathrm{~km}$ a further increase in the seismic velocity of $\mathrm{p}_{\mathrm{g}}$-phases occurs 
on the seismic recordings. This is due to higher velocities of $\sim 7.2 \mathrm{~km} \mathrm{~s}^{-1}$ at 15 to $20 \mathrm{~km}$ depth along the continent-ocean transition. Moho reflections $\left(\mathrm{p}_{\mathrm{m}} \mathrm{p}\right)$ occur consistently at 6 to $7 \mathrm{sec}$ all along the eastern profile section. Later arrivals are often observed in the vicinity of $\mathrm{p}_{\mathrm{m}} \mathrm{p}$-reflections and exhibit very large apparent seismic velocities. Subsequent raytracing of the data shows that these phases can not be consistently explained by a single steep dipping boundary. Instead, we attribute them to large lateral variations along the continental margin and possibly 3D-effects. $\mathrm{P}_{\mathrm{n}}$-phases, for determination of upper mantle seismic velocities were recorded on various stations and are characterised by strong amplitude variations (Figure 2a). This might be ascribed to scattering of seismic energy due to a strong basement- and Moho topography along the oceanic section. The data of OBH277 (Figure 2c), located directly above the Horsund Lineament, allows us to observe the characteristics of the continent-ocean transition. Here, first arrivals at near offsets $(<20 \mathrm{~km})$ indicate seismic velocities of 1.7 to $3.5 \mathrm{~km} \mathrm{~s}^{-1}$ for the sedimentary cover on the shelf. As observed on example ref277 the $\mathrm{p}_{\mathrm{g}}$-phase penetrating the middle crust shows strongly variable seismic velocities between $\mathrm{km} 110$ and 160 . This is mainly due to the bathymetry, a varying thickness of the sedimentary cover and the lateral inhomogeneous sub-sedimentary crustal construction.

The crust-mantle boundary is defined by $\mathrm{p}_{\mathrm{m}} \mathrm{p}$ reflections that are located within a strong reverberation pattern (Figure 2c). The velocity structure of oceanic crust is demonstrated by the recording of station obs14 (Figure 2d; see also $3 b$ for station OBS12). At near offsets first arrivals are crustal $\mathrm{p}_{\mathrm{g}}$-phases that are ascribed to oceanic layer $2\left(3.5-4.5 \mathrm{~km} \mathrm{~s}^{-1}\right)$. At near critical distances of 10 to $15 \mathrm{~km}$ first arrivals exhibit velocities of $\sim 7.9 \mathrm{~km} \mathrm{~s}^{-1}$ (and higher) which we interpret as $p_{n}$-arrivals. Due to the position of station OBS14 in the median valley of the Knipovich Ridge proximal $\mathrm{p}_{\mathrm{n}}$-phases show anomalous high apparent velocities (large bathymetric differences in depth). Phase-undulations and amplitude variations of $\mathrm{p}_{\mathrm{n}}$-phases are due to a strong basement and Moho topography commonly found.

\section{Seismic reflection data - acquisition}

Seismic reflection data between the Knipovich Ridge and the Bellsund (Figure 1) was collected on cruise leg III of RV Håkon Mosby in 1999 (profile 7/AWI$99530 ; 5.2^{\circ} \mathrm{E}-13.5^{\circ} \mathrm{E}$ ). This survey was carried out in
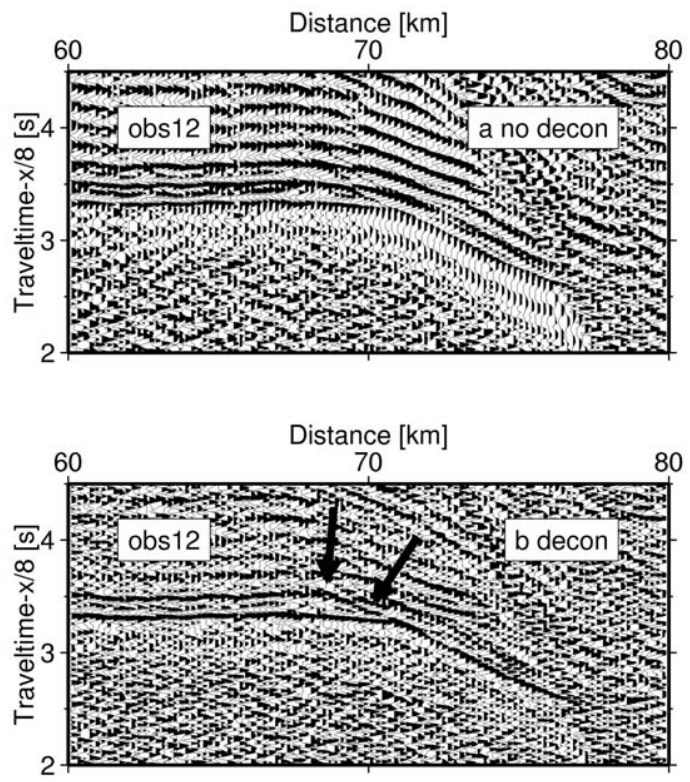

Figure 3. a and b. Example for deconvolution on OBS12. The upper figure (a) shows an enlargement of the recording of OBS12 $(20 \mathrm{~km}$ to the east of the station). Data are filtered with a bandpass filter $(5-17 \mathrm{~Hz})$ and scaled by automatic gain control (1 s). The lower data set (b) shows the results of deconvolution after filtering and subsequent filtering as discussed in the text. Note, that the strong reverberation pattern in the upper figure at $70 \mathrm{~km}$ is suppressed after applying deconvolution (black arrows).

cooperation with the Norwegian Petroleum Directorate and Norsk Hydro. The hydrophone cable (3000 m) comprised 120 channels with a group spacing of $25 \mathrm{~m}$. A seven airgun array with a total charge of 471 was used to produce the acoustic energy. The resulting length of the profile is $233 \mathrm{~km}$ ( 5000 shots) parallel to the seismic refraction lines.

\section{Seismic reflection data - processing and characteristics}

Stacking was done using a CDP-distance of $50 \mathrm{~m}$ (fold=30), following processing sequence comprehends prestack-filtering in the f-k-domain, to reduce strong water bottom multiples from the upper shelf to the deep sea environment east of Knipovich Ridge (CDPs 6400-9400). CDP-gathers are (i) nmocorrected and (ii) overcorrected, to separate primary and multiple reflections according to their apparent velocities within the $\mathrm{f}-\mathrm{k}$ domain. Subsequent filtering eliminates seismic energy in the quadrant $\mathrm{k}>0$. Finally, the applied overcorrection was removed and the data were stacked. To display the section, data were bandpass filtered within the upper $3 \mathrm{~s}$ passing 


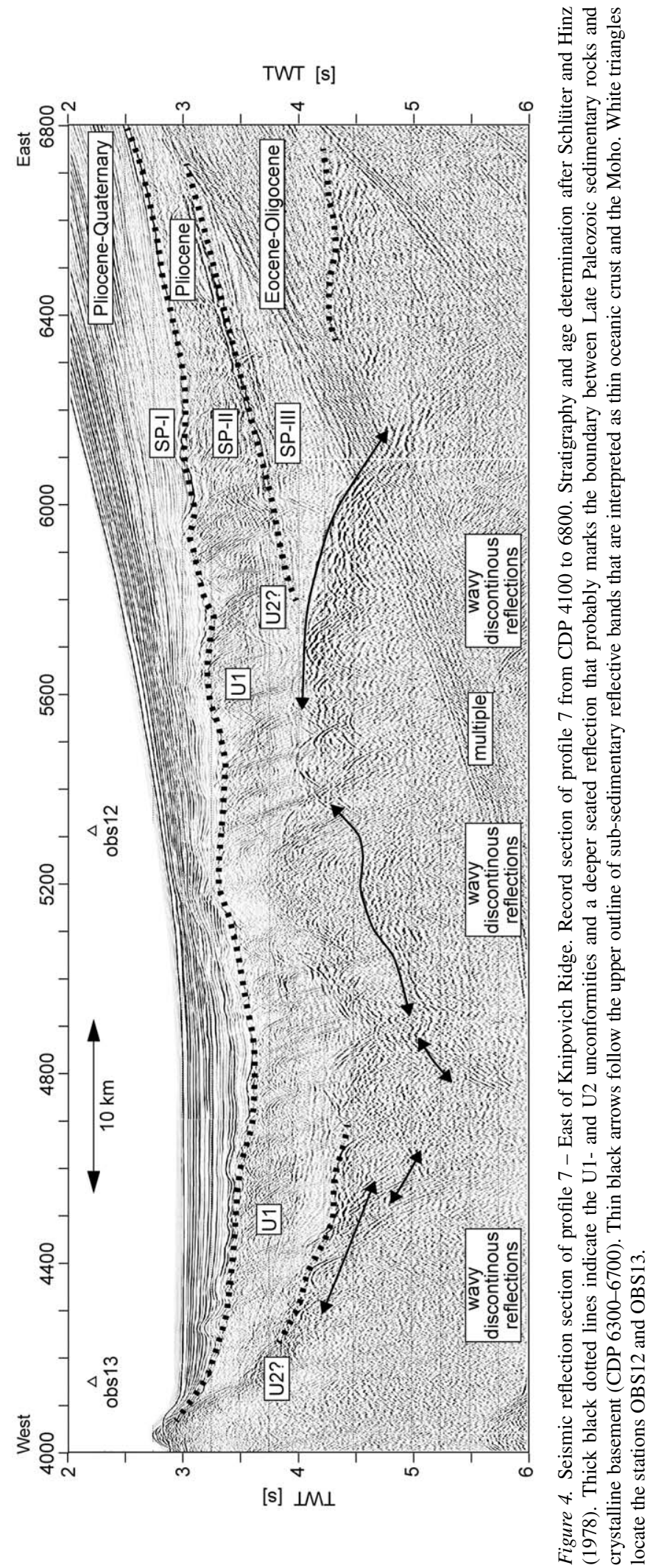


frequencies of 18 to $75 \mathrm{~Hz}$ and with reduced high-cut frequencies thereafter to reduce high-frequency noise in the region of basement and sub-basement reflections ( $<55 \mathrm{~Hz}$ between 3 and $4 \mathrm{~s} ;<45 \mathrm{~Hz}$ below $4 \mathrm{~s}$ ). Seismic traces were scaled using a $200 \mathrm{~ms}$ automatic gain control.

Figure 4 shows the seismic reflection data for the oceanic crustal section east of Knipovich Ridge. The upper parts are characterised by continuous reflections with a thickness of 0.5 to $2 \mathrm{~s}$ (twt). Beneath this a diffractive event at 3 to $3.5 \mathrm{~s}$ (twt) caps a mostly transparent part of the data, with continuous reflections occurring only east of CDP 5600 between 3 and $3.5 \mathrm{~s}$ (twt). Reflections below $4 \mathrm{~s}$ (twt) show a discontinuous wavy pattern in a $0.5 \mathrm{~s}$ (twt) thick band. Along the profile section this sub-sedimentary reflective band describes two antiforms with their summits located at CDP $\sim 4200$ and $\sim 5600$.

\section{Gravity data}

Gravity data along the seismic refraction transects AWI-97260 and profile 9 was extracted from the freeair anomaly grid of Boebel (2000). This grid is mainly based on airborne gravity measurements and secondary shipborne data. The grid cells measure $20^{\prime} \times 5^{\prime}$. It provides a continuous free-air anomaly profile along both seismic profiles and the landward extension in Heer Land.

\section{Modelling of refraction data}

Seismic refraction data gathered along profiles AWI97260 and profile 9 comprise 22 stations that are used for raytracing. We performed the modelling with the software package rayinvr of Zelt and Smith (1992). After picking of clear high-amplitude arrivals, which were mostly first arrivals and Moho-reflections, 1Dmodels for each station were calculated. These 22 single 1D-profiles were gathered to a final $360 \mathrm{~km}$ long 2D-transect ( -50 to $290 \mathrm{~km}$; Knipovich Ridge is located at $0 \mathrm{~km}$ ). Suitable uncertainty values (error bars) were assigned to all traveltime picks: Depending on the S/N-ratio, the phase correlation quality and the signal shape (reverberations), uncertainties between 0.1 and $0.45 \mathrm{~s}$ were assigned (Table 1). About $90 \%$ of $\mathrm{p}_{\mathrm{g}}$-phase traveltime picks obtained an uncertainty of $<=0.15 \mathrm{~s}$, which includes at least one reverberation cycle. Greater uncertainties of 0.35 to 0.45 were used only for $5 \%$ of the traveltime picks. In most cases it concerns large distance $\mathrm{p}_{\mathrm{n}}$-phases (more than $150 \mathrm{~km}$ distance) or Moho-reflections with low S/N-ratio.

Generally, a forward modelling technique was applied, in which the modelling took place layer by layer. Velocity-depth nodes were held fixed when the next, deeper layer was modelled. Improved traveltime fits come with the addition of nodes in the model, especially along the oceanic section. We put more emphasis on matching the slope and shape of the observed traveltimes branches than on minimizing the traveltime residual provided by the program rayinvr. We interpret first arrivals commonly as diving waves, since gradients are mostly observed. An exception is the mantle layer, whose velocity structure was modelled using head-waves.

Using this initial model, we calculated traveltimes for phases at stations where the S/N-ratio had caused problems. These data were inspected a second time in order to search for additional low amplitude arrivals. Of the 3400 picks in the final set, about $35 \%$ are $\mathrm{p}_{\mathrm{n}^{-}}$ phases or $\mathrm{p}_{\mathrm{m}} \mathrm{p}$-reflections. Approximately two thirds are located east of $\mathrm{km} 120$ along the continental profile section. This reflects the close receiver spacing there. The final fit of observed traveltimes was derived from two runs of the inversion method of rayinvr to the velocity model. Raytracing examples for the different crustal sections (oceanic crust, continent-ocean transition, continental crust) are shown in Figures 5a-f. Figures 5a-f show example raypaths for six stations (OBS14, OBS16, OBH279, ref275, ref273 and ref263) which cover different crustal sections along the entire transect. In these figures all the important modelled structures are densely sampled by rays, with the exception of the deeper continental crust east of $\mathrm{km}$ 180. This is only constrained by wide-angle reflections (Figures 5e and f).

\section{Resolution and uncertainty of the modelled velocity structure}

The reliability of the final velocity structure is expressed in the resolution calculated by the inversion algorithm of rayinvr (Zelt and Smith, 1992). This quantitative approach of rayinvr is based on the relative number of rays which determine or assign the parametrisation, i.e., the velocity nodes. According to Zelt and Smith (1992) resolution values of 0.5 or greater are considered to be well resolved. A resolution is calculated for each velocity node in our final model, and these are interpolated onto a $0.5 \times 1.0 \mathrm{~km}$ grid 

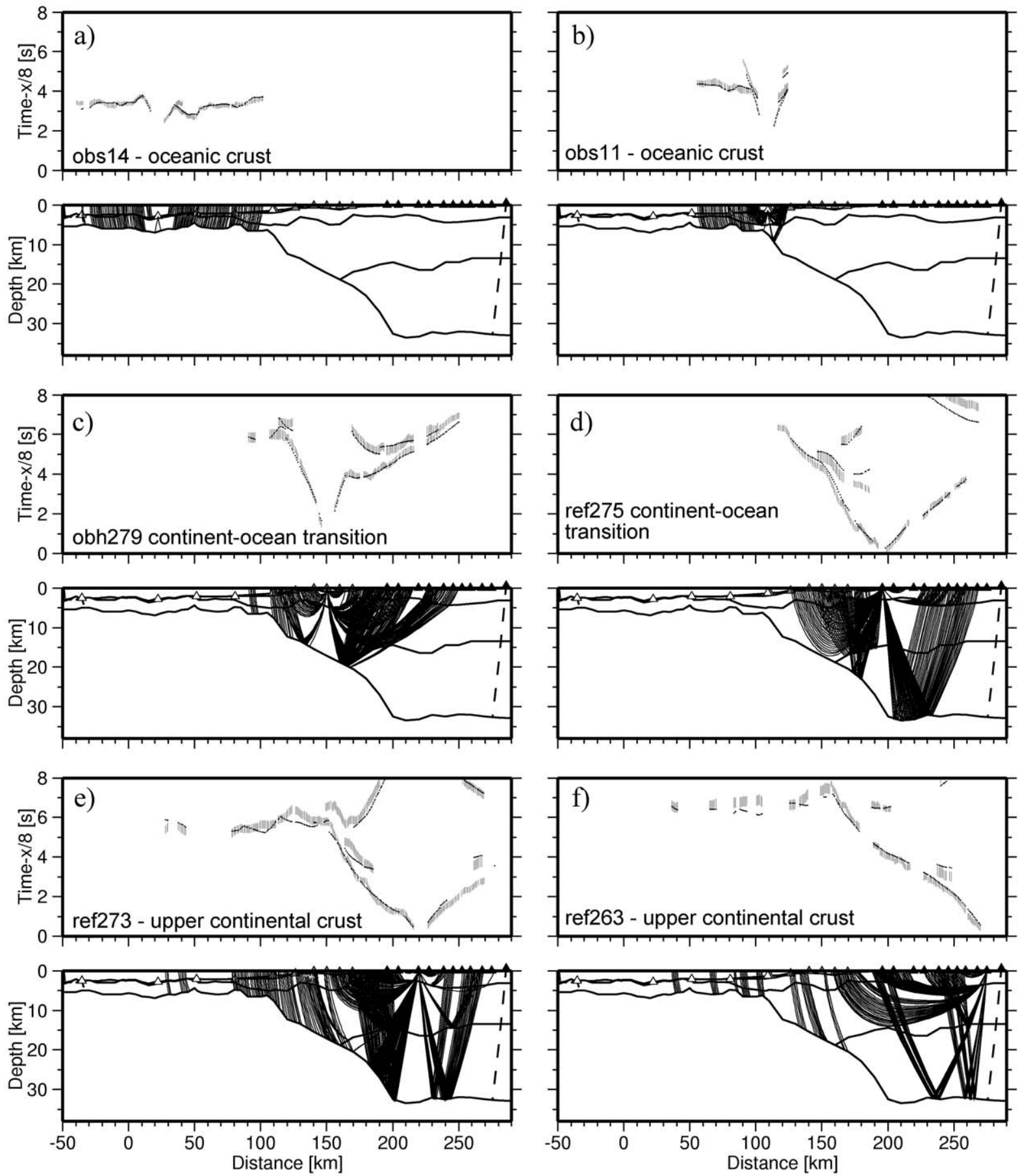

Figure 5. a-f. Examples of raytracing along the profiles AWI-97260 and profile 9. Examples of raytracing of data from stations (a) OBS14, (b) OBS11, (c) OBH279, (d) ref275, (e) ref273 and (f) ref263. The six examples cover different parts of the refraction transect. The upper parts of a-f show the observed and calculated p-wave arrivals. Gray errors bars indicate the assigned error to the picked traveltimes. Black lines show the traveltimes calculated using the final velocity model shown in Figure 6 . The lower figures of a-f are the respective paths for rays calculate by rayinvr (Zelt and Smith, 1992). 
Table 1. (Modelling results - over all phase statistics) Over all phase statistics of the final velocity model. The statistic is subdivided into the oceanic and transitional-continental profile sections, respectively. Indexes: s offshore sedimentary basins, cb onshore cenozoic sedimentary basins, g deeper crustal phases including Paleo- and Mesozoic sedimentary basins, $\mathrm{m}$ Moho. Rms-misfits and $\chi^{2}$-values after Zelt \& Smith (1992).

\begin{tabular}{|c|c|c|c|c|c|}
\hline Section & Phase & Points used & Assigned errors [s] & rms-misfit [s] & $\chi^{2}$ \\
\hline Oceanic & $\mathrm{p}_{\mathrm{s}}$ & 55 & $0.10-0.20$ & 0.21 & 3.11 \\
\hline \multirow[t]{4}{*}{$<\mathrm{km} 110$} & $\mathrm{p}_{\mathrm{s}} \mathrm{p}$ & 35 & $0.10-0.20$ & 0.21 & 2.30 \\
\hline & $\mathrm{p}_{\mathrm{m}} \mathrm{p}$ & 65 & 0.10 & 0.09 & 0.89 \\
\hline & $\mathrm{p}_{\mathrm{m}} \mathrm{p}$ & 12 & $0.10-0.30$ & 0.22 & 0.80 \\
\hline & $\mathrm{p}_{\mathrm{n}}$ & 379 & $0.10-0.25$ & 0.18 & 1.55 \\
\hline trans. - cont. & $\mathrm{p}_{\mathrm{s}}$ & 49 & $0.15-0.25$ & 0.30 & 1.73 \\
\hline \multirow[t]{6}{*}{$>$ km 110} & $\mathrm{p}_{\mathrm{cb}}$ & 381 & $0.15-0.20$ & 0.17 & 1.25 \\
\hline & $\mathrm{p}_{\mathrm{cb}} \mathrm{p}$ & 9 & 0.15 & 0.32 & 5.13 \\
\hline & $\mathrm{pg}_{\mathrm{g}}$ & 1118 & $0.15-0.25$ & 0.24 & 2.23 \\
\hline & $\mathrm{pg}_{\mathrm{g}}$ & 273 & $0.15-0.35$ & 0.30 & 1.41 \\
\hline & $\mathrm{p}_{\mathrm{m}} \mathrm{p}$ & 460 & $0.15-0.45$ & 0.57 & 2.25 \\
\hline & $\mathrm{p}_{\mathrm{n}}$ & 557 & $0.15-0.40$ & 0.35 & 1.87 \\
\hline Entire model & all phases & 3393 & - & 0.31 & 1.93 \\
\hline
\end{tabular}

(Figure 6, assumed velocity- and boundary uncertainty was $0.2 \mathrm{~km} \mathrm{~s}^{-1}$ and $0.2 \mathrm{~km}$, respectively).

The resulting calculated resolution is shown in Figure 6. Continental crust east of $\mathrm{km} 120$ and the Cenozoic sedimentary section are in general well resolved, exhibiting values between 0.5 and 0.9 . Exceptions occur at the outer sides of the middle and upper layers, where resolution decreases to 0.4 and below. Along the oceanic crustal section the resolution is satisfying in the vicinity of the deployed receivers ( 0.3 to 0.8$)$ but decreases below 0.2 at the positions between. The mantle layer is generally well resolved west of $\mathrm{km} 150$ due to the large number of $\mathrm{p}_{\mathrm{n}}$-phases on most seismic recordings $(0.6$ to 0.9$)$. To the east mantle resolution decreases rapidly $(\sim 0.3)$ since critical distances $p_{n}{ }^{-}$ phases are too large to penetrate the upper mantle in depths of $>30 \mathrm{~km}$.

Further contraints of the reliability of the final velocity model are given by the RMS-misfit and the $\chi^{2}$-normalised misfit parameter provided by rayinvr (Zelt and Smith, 1992). Table 1 shows the results applied for each phase along the oceanic and transitionalcontinental sections, repectively. An $\chi^{2}$-value equal to 1 indicates that data is fitted within their assigned uncertainties. Variations of $\chi^{2}$ to values lower than 1 indicate the presence of structures not required by the traveltime picks. This is in particular the case along the oceanic part, where additional nodes were inserted in order to match phase-undulations due to basement- and Moho-topography (Figure 2d). Along the eastern continental part of the profile the normalised mistfit increases to values higher than 1 .

According to Zelt and Smith (1992) a non-linear shot-receiver geometry and 3D effects increase $\chi^{2}$. We regard the calculated misfits listed in Table 2 as acceptable, since (i) the continental section of the profile is surveyed by a land-sea seismic experiment. Therefore a non-linear experimental setup is given. Further, (ii) the ancient terrane/orogenic and fault tectonics of Svalbard give rise to the assumption that a complex 3D subsurface geology can further distort the 2D analysis of seismic data. Fortunately, the key stations that resolve the complex continent-ocean transition zone show satisfying $\chi^{2}$-values near 1 (e.g., station OBH279, km 150.3, $\chi^{2}=1.15$ ).

The uncertainty of the depth level of the model horizons, defined by wide-angle reflections can be estimated by shifting it both up and down, until the calculated traveltime no longer fit. This method depends strongly on the assigned traveltime errors, which show a large variance (s.a.). Due to the large amount of station and given raycoverage we estimate the depth uncertainty to $\sim 1 \mathrm{~km}$ for horizons shallow than $10 \mathrm{~km}$ depth. At larger depths the depth uncertainty increases to $\sim 1.5 \mathrm{~km}$ (mid crustal reflector) and $<2.5 \mathrm{~km}$ (Moho). 


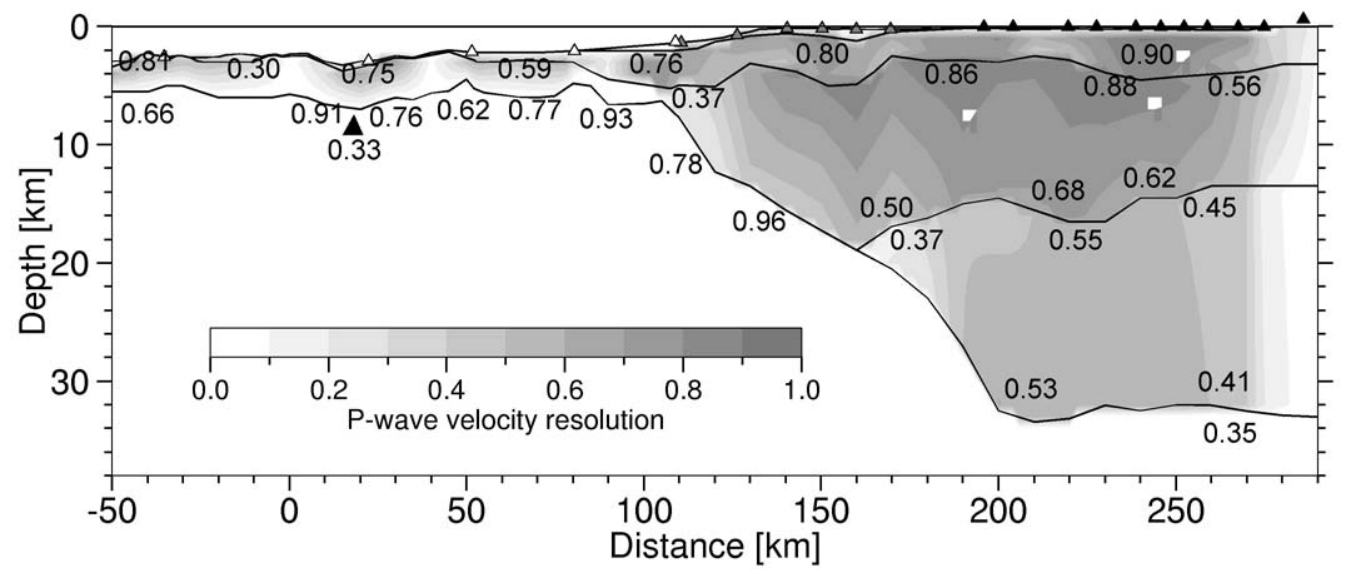

Figure 6. Resolution of the final p-wave velocity model. Resolution of the p-wave velocity field calculated by rayinvr (Zelt and Smith, 1992), resampled to $20 \mathrm{~km}$ intervals. The grayshade shows the resolution, as well as the single shown values. Triangles as for Figure 1.

\section{Results and interpretation}

The final velocity model along the profiles AWI97260 and profile 9 is shown in Figure 7. A line drawing interpretation of profile 7 is superimposed. The following section contains detailed descriptions of the velocity model as well as our favoured interpretation of the observed structures. Figure 8 shows the final geological interpretation of the Knipovich Ridge-Bellsund-Van Mijenfjorden seismic transect.

\section{Sedimentary cover}

Sediments and sedimentary rocks east of Akseløya $(\mathrm{km}$ 190 to 290). Between Akseløya and the eastern end of the profile in Heer Land (Figure 1) the seismic velocities of the upper layer of the velocity model range from 4.5 (4.6) to $5.4 \mathrm{~km} \mathrm{~s}^{-1}$ (Figure 7). The middle layer exhibits low seismic velocities between 5.6 and $6.0 \mathrm{~km} \mathrm{~s}^{-1}$ in a trough-like structure down to depths of $15 \mathrm{~km}$.

After Harland (1997d) the estimated thickness of Paleocene-Eocene strata of the Central Spitsbergen Basin amounts to $\sim 2.5$ to $3.5 \mathrm{~km}$. This thickness coincides with the $5.0 \mathrm{~km} \mathrm{~s}^{-1}$-velocity contour. Velocities greater than $5.0 \mathrm{~km} \mathrm{~s}^{-1}$ are interpreted therefore as older (Carboniferous/Permian to Cretaceous) sedimentary rocks below. Where these crop out between Akseløya and station ref270 (Figure 1) the velocity model shows seismic velocities of $5.4 \mathrm{~km} \mathrm{~s}^{-1}$ at the surface (Figure 7). Similar velocities are observed for Late Paleozoic to Mesozoic sedimentary rocks of northern Greenland and Svalbard (Jackson, 1990; Hajnal et al., 1990; Eiken, 1994). Devonian sed- imentary rocks of the Nordfjorden Block $(\mathrm{km} 220$ to 270) are suggested to be present below the Central Spitsbergen Basin (Johannessen and Steel, 1992; Nøttvedt et al., 1993). Based on velocities for Devonian sedimentary rocks of up to $6.0 \mathrm{~km} \mathrm{~s}^{-1}$ found in northern Svalbard and on the southern Yermak Plateau (Ritzmann and Jokat, 2003), we propose that the reflective horizon at depths of 12 to $15 \mathrm{~km}$ marks the base of Devonian deposits. The eastern termination of the Nordfjorden Block is marked by the Billefjorden Fault Zone at km 275 (Figure 1; ref263). Here seismic velocities increase within the middle crust to 5.9$6.4 \mathrm{~km} \mathrm{~s}^{-1}$. Crystalline basement is supposed to have been thrusted over Devonian sedimentary strata along the westward verging Billefjorden Fault. In the Late Carboniferous this uplifted basement section experienced downfaulting further east (Heer Land), so that deep sedimentary basins developed (Nøttvedt et al., 1993). The observed velocity structure does not illustrate these events (Figure 7). We attribute that to the limited extension of our profile east of the fault $(\times 15 \mathrm{~km})$, although the western flank of the basement high is well resolved. In contrast the western flank of the Nordfjorden Block is clearly evidenced by the increase of seismic velocities at $\mathrm{km} \mathrm{200-220}$ $\left(6.1-6.6 \mathrm{~km} \mathrm{~s}^{-1}\right)$. This zone coincides with the surface trace of the Kongsfjorden-Hansbreen Fault Zone (the proposed boundary between Svalbard's central and western terranes).

Sediments and sedimentary rocks of the western shelf and deep sea environment ( $\mathrm{km} 50$ to 180). Off Van Mijenfjorden ( $\mathrm{km} 70$ to 160) the upper layer of the velocity model exhibits seismic velocities ranging 


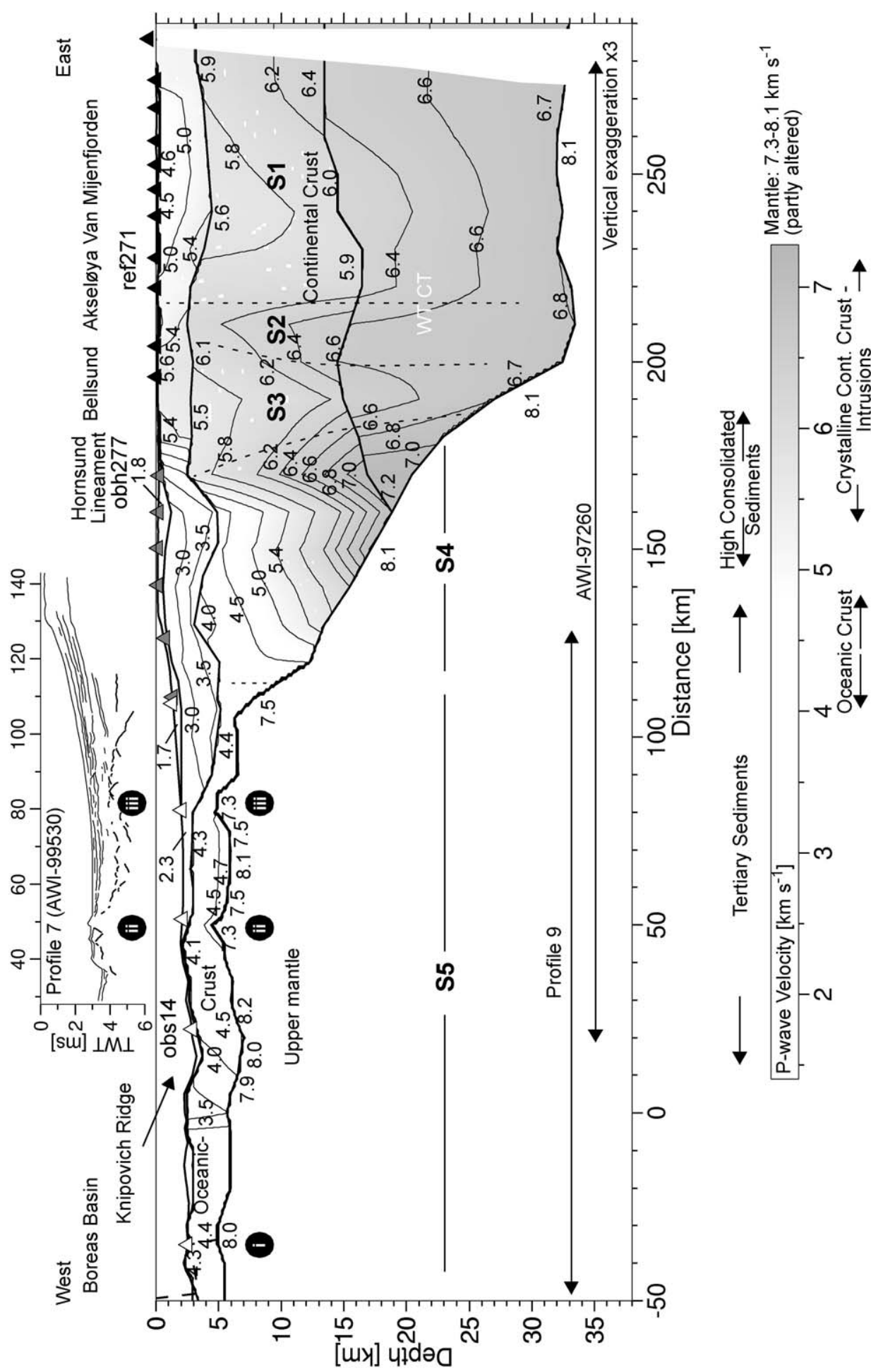

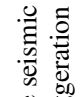

담

है

要

农

总导

$\vec{F}$

$\sigma 0$

0
0
0
0
0
0
0

吾的总

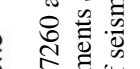

o을

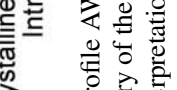

合

응

政

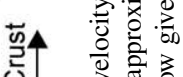

D.

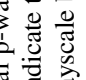

踏

色总

递嵒

를

焉 鹿

品言

돈

o 흥

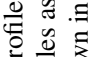

客. 흠

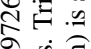

is

政

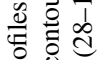

웜

을 현

突

용

政

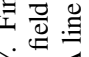

류

in 


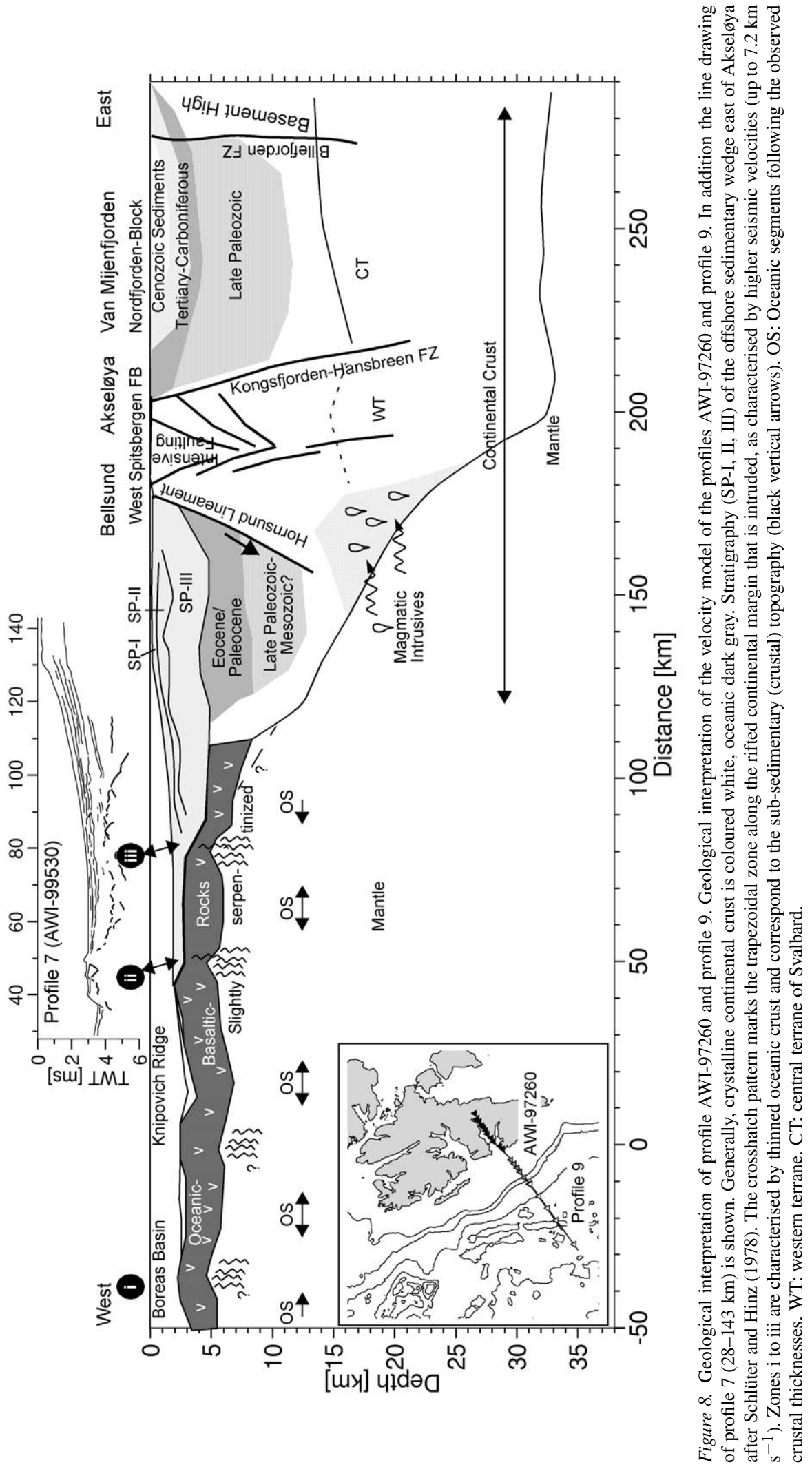


from $1.7-1.8 \mathrm{~km} \mathrm{~s}^{-1}$ at the top to $3.5-3.9 \mathrm{~km} \mathrm{~s}^{-1}$ at the bottom. This layer comprises Cenozoic sedimentary strata. The thickness of this model layer varies between 2 and $5 \mathrm{~km}$. Seismic velocities for the sedimentary sequences off Van Mijenfjorden found by Schlüter and Hinz (1978) and Myhre and Eldholm (1988) range between 1.7-3.8 $\mathrm{km} \mathrm{s}^{-1}$ and 1.9$3.7 \mathrm{~km} \mathrm{~s}^{-1}$, respectively. Schlüter and Hinz (1978) observed two sedimentary unconformities U1 (Pliocene, 3.5 Ma) and U2 (Eocene-Oligocene, 36 Ma) subdividing the offshore sedimentary record off Van Mijenfjorden into three sequences (SP-I, SP-II and SPIII; see also Figure 4). They suggest the absence of Oligocene-Miocene sedimentary strata above U2 due to a major drop in sea-level in Oligocene times. South of $76^{\circ} \mathrm{N}$ Myhre and Eldholm (1988) observed the gradual extinction of U2, giving way to a continuous post-Eocene sequence.

The lower boundary of the modelled upper sedimentary layer at km 120 (5 km depth; Figure 7) shows a ridge, that is inferred from early p-wave arrivals on station $\mathrm{OBH} 281$, with velocity of $>4.0 \mathrm{~km} \mathrm{~s}^{-1}$. We interpret this phase to be derived from sedimentary units. The nature of the deeper seated refractors (SPIII; Figure 4) with seismic velocities of $4.5-5.5 \mathrm{~km} \mathrm{~s}^{-1}$ is uncertain (Myhre and Eldholm, 1988). Comparing these velocities found with those in the Tertiary Central Spitsbergen Basin (4.5-5.0 $\mathrm{km} \mathrm{s}^{-1} ; 220-270 \mathrm{~km}$ ) it is plausible that lower SP-III comprises Early Tertiary (Paleocene/Eocene) or even older sequences. The inferred depth of the base of the Paleocene is with respect to the $5.0 \mathrm{~km} \mathrm{~s}^{-1}$-isovelocity contour, at 9 to $10 \mathrm{~km}$ depth. After Harland (1997d) the thickness of Paleogene sedimentary rocks in the Central Spitsbergen Basin is 2.5 to $3.5 \mathrm{~km}$, which is comparable to that observed to the west of the orogenic belt.

Mann and Townsend (1989) and Townsend and Mann (1989) suggest still older (Carboniferous) sedimentary deposits below the Bellsund in the Bellsundbanken Graben. It is uncertain if this graben extends further west across the Hornsund Lineament. In the case of occurrence of Late Paleozoic sedimentary rocks the $5.5 \mathrm{~km} \mathrm{~s}^{-1}$ contour might mark the sediment-basement boundary (10.5 to $12 \mathrm{~km}$ depth), analog to velocities found elsewhere (Jackson, 1990; Hajnal et al., 1990; Eiken, 1994). This would therefore imply a total offshore sedimentary thickness of about $10 \mathrm{~km}$, from a crustal thickness of 13 to $20 \mathrm{~km}$ (120-160 km; Figure 7). A strong band of continuous reflections (4.2 to $4.6 \mathrm{~s}$ twt) in the seismic reflection data of profile 7 might be represent the upper sec- tion of the supposed Late Paleozoic (and younger) sedimentary rocks (Figures 4 and 7, line drawing; CDP 6300-6700; also observed by Schlüter and Hinz (1978), line 25 at $\sim 5 \mathrm{~s} \mathrm{twt}$ ).

Between -50 and $60 \mathrm{~km}$ the thickness of the sedimentary cover on oceanic crust decreases to a maximum of $1.5 \mathrm{~km}$. Locally thicknesses of only 100 to $200 \mathrm{~m}$ are observed, and some oceanic basement ridges feature no modelled sedimentary cover (e.g., $45 \mathrm{~km}$ ). Seismic velocities at the top of the sedimentary section are $\sim 1.7 \mathrm{~km} \mathrm{~s}^{-1}$, at the base velocities do not exceed $2.3 \mathrm{~km} \mathrm{~s}^{-1}$.

Tertiary sedimentary strata are further expected east of the Hornsund Lineament within a $28 \mathrm{~km}$ wide graben centred on $180 \mathrm{~km}$ that is most probably a similar feature to the Forlandsundet Graben north of Isfjorden (Eiken and Austegard, 1987; Eiken, 1994). About $4 \mathrm{~km}$ of sedimentary deposits (2 s twt) are observed (Eiken, 1994). Due to the failure of OBH276 at $183 \mathrm{~km}$ on top of this graben no sedimentary (low velocity-) phases were detected. Therefore the seismic velocity structure of the graben remains unexplored. Only the bounding basement-flanks are constrained.

\section{Continental crust}

The eastern continental profile section along $\mathrm{km} 190$ to 290 comprises Svalbard's western and central basement terranes (Harland and Wright, 1979; Harland, 1997b). The Caledonian docking of these terranes, the Tertiary Spitsbergen Orogeny (Steel et al., 1985; Harland, 1997c) and post-Oligocene rifting are the major tectonic events that affected the continental crustal structure.

Caledonian terranes (S1-S2). The Caledonian suture is supposed to be located at the sinistral KongsfjordenHansbreen Fault Zone (Harland and Wright, 1979) which is located at $\mathrm{km} \sim 215$. Here, the upper and lower units of the crust show a striking change in seismic velocities (Figure 7; S1-S2). The lateral change in velocity at depths above $12 \mathrm{~km}$ is attributed to the boundary of the Devonian sedimentary rocks (Nordfjorden Block). Nevertheless, within the middle and lower crust the western terrane exhibits higher velocities of $6.6 \mathrm{~km} \mathrm{~s}^{-1}$, compared to $6.2 \mathrm{~km} \mathrm{~s}^{-1}$ in the central terrane (Figure 7). Only a narrow section of the western terrane at $\mathrm{km} \sim 220$, can be classified as unaffected by the Tertiary Spitsbergen Orogeny, as the Tertiary Spitsbergen Fold Belt adjoins this section. The total range of seismic velocities of continental 
crust along segments $\mathrm{S} 1$ and $\mathrm{S} 2$ can be compared to the work of Chan and Mitchell (1982) and Amundsen et al. (1987) who determine velocities of 6.1$6.3 \mathrm{~km} \mathrm{~s}^{-1}, 6.4-6.6 \mathrm{~km} \mathrm{~s}^{-1}$ and $6.7-6.8 \mathrm{~km} \mathrm{~s}^{-1}$ for northwestern Svalbard (Woodfjorden; Figure 1). This three layer structure and related mid-crustal reflections (Ritzmann and Jokat, 2003) are not seen in southern Svalbard. The depth to the Moho is about $34 \mathrm{~km}$ below the Van Mijenfjorden, and in good agreement to depths published by Sellevoll et al. (1991) and Faleide et al. (1991). Sellevoll et al. (1991) suppose a crust-mantle transitional layer $\left(7.8 \mathrm{~km} \mathrm{~s}^{-1}\right)$, but in contrast our data indicate a first-order discontinuity at the Moho (Figure 7). High lower crustal seismic velocities (Czuba et al., 1999; 7.2 to $7.3 \mathrm{~km} \mathrm{~s}^{-1}$ ) are further not confirmed by our transect.

West Spitsbergen Fold Belt (S3). The West Spitsbergen Fold Belt extends approximately from the position of OBH277 to Akseløya (km 170-210; Figure 1) along Svalbard's western terrane. The deeper seismic velocity structure exhibits a 20 to $30 \mathrm{~km}$ wide trough-like structure. In the centre at $\mathrm{km} 190$ low velocities of 5.5 and $6.2 \mathrm{~km} \mathrm{~s}^{-1}$ and 6.4 to $6.8 \mathrm{~km} \mathrm{~s}^{-1}$ are observed for the middle and lower crust, respectively. In contrast the flanks have higher velocities, e.g., $6.2 \mathrm{~km} \mathrm{~s}^{-1}$ at 5 to $10 \mathrm{~km}$ (Figure 7). Due to the failure of OBH276 the upper $5 \mathrm{~km}$, which feature the Tertiary graben below the Bellsund (Eiken and Austegard, 1987; Eiken, 1994) is not well resolved.

Models for the evolution of the West Spitsbergen Fold Belt are generally based on the transpressive movements between Svalbard and Greenland during the Late Paleocene to Eocene (Lowell, 1972; Steel et al., 1985; Müller and Spielhagen, 1990; Harland, 1997c). Thrust faults of the fold belt steepen with depth and towards the centre of the belt. Further, geological mapping shows that local strike-slip faults pass over into thrusts (Kellog, 1975; Steel et al., 1985). This leads to the assumption of a large flower structure model for the fold belt (Lowell, 1972; Myhre et al. 1982; Nøttvedt et al., 1993). A principal problem is the subsidence of the graben system along Svalbard's west coast within this mostly transpressive regime (e.g., Forlandsundet Graben, Tertiary graben below the Bellsund; Steel et al., 1985; Eiken, 1993, 1994). Steel et al. (1985) supposed local extension adjacent to a curved strike-slip zone or a collapse scenario in the central part of the uplifted and arched orogenic belt. Gabrielsen et al. (1992) show that the Forlandsundet
Graben is bounded by steep marginal faults with a dip-slip character.

From the observed velocity structure we favour kinematic models with steep, vertical (strike-slip) faults that penetrate much of the crust (e.g., Lowell et al.'s (1972) flower structure). We assume convergent motion along these faults to fracture extensively the brittle rock construction of the upper and middle crust (and result in possible deep seated mylonitic rocks). After the transpressive orogenic phase (Late Paleocene to Eocene), the stress field changed along western Svalbard to transtension from Oligocene onwards (Eldholm et al., 1987). Thenceforward, tensional release occurred at the centre of the fold belt leaving behind an intensively brittle-fractured rock formation.

The continent-ocean transition S4 (110 to 190). The continent-ocean transition is marked by a gradual decrease of crustal thickness within a broad zone of approximately $80 \mathrm{~km}$ (Figure 7). The Moho depth shallows from $\sim 34 \mathrm{~km}$ along the central terrane to $\sim 8 \mathrm{~km}$ at the transition to the oceanic crust. Two steep sections with an eastward dip of $\sim 30^{\circ}$ occur at $\mathrm{km} 120$ and 190. Seismic velocities in the segment S4 lower than $5.5 \mathrm{~km} \mathrm{~s}^{-1}$ are interpreted as Late Paleozoic to Mesozoic sedimentary rocks. The isovelocity contour lines describe a steep lateral decrease of seismic velocity towards the west between $\mathrm{km} 160$ and 180 (5 to $15 \mathrm{~km}$ depth). Here, a lateral velocity gradient of $\sim 0.1$ $\mathrm{s}^{-1}$ is observed (Figure 7). The occurrence of the large lateral velocity gradients in the upper and middle crust coincides with the position of the Hornsund Lineament (Myhre and Eldholm, 1988; Eiken, 1993). Eiken and Austegard (1987) interpret the Hornsund Lineament off Van Mijenfjorden as two east-verging faults bounding a rotated crustal block. The westward dip (listric?) of the velocity contours might support this interpretation, keeping in mind that highly consolidated sedimentary rocks might build up the top of this block.

The velocity structure at the crust-mantle transition features high seismic velocities of $7.2 \mathrm{~km} \mathrm{~s}^{-1}$ (150 to $170 \mathrm{~km}$ ): the highest seismic velocity within continental crust along the entire profile. Although the calculated resolution is low (0.37 to 0.5$)$ key stations at the continent-ocean transition zone do constrain the increase of seismic velocity very well (e.g., Figure 5d, station ref275). This zone of elevated velocities is interpreted as altered crust. A (maximum) $40 \times 8 \mathrm{~km}$ wide trapezoidal body of higher velocities is observed at 15 to $25 \mathrm{~km}$ depth. Elevated seismic velocities in 
the deeper crust at continental margins are associated with mantle derived mafic/ultramafic melts and are a common phenomenon at rifted volcanic margins emplaced by underplating and intrusions (White and McKenzie, 1989). A rifted volcanic margin history for the western Svalbard margin is excluded, since seismic refraction data in proximity to the proposed Yermak hot spot (Feden et al., 1979; Jackson et al., 1984) reveals no indications for a volcanic evolution (Ritzmann and Jokat, 2003). Oceanic crust adjacent to rifted volcanic margins exhibits enhanced thicknesses (White and McKenzie, 1992) which is not observed off Van Mijenfjorden (Figure 7; 70-110 km). The continent-ocean transition marks the western flank of the Spitsbergen Shear Zone, the proposed Oligocene boundary between Svalbard and Northeast Greenland (Crane et al., 1991). Due to a transtensional tectonic regime, lithospheric thinning is suggested along this mega shear. As a result of the low lithospheric load decompressive melting most probably occurred and provided ideal paths for the distribution of melts along the shear zone (known as 'thin spots' in relation to mantle plumes; Thompson and Gibson, 1991). Considerable sources for mantle derived melts along the Spitsbergen Shear Zone are (i) the Eocene-Oligocene Vestbakken Volcanic Province (central-western Barents Sea margin; Faleide et al., 1993) or the (ii) Oligocene decompressive melting below the southern Yermak Plateau (simple shear extension; Ritzmann and Jokat, 2003). The (iii) northward propagating Knipovich Ridge (Crane et al., 1991; Boebel, 2000) could also be the source of mantle derived melts. Tectonic reconstructions of Crane et al. (1991) and Boebel (2000) place the northernmost Knipovich Ridge in close proximity to the Hornsund Lineament at the continental margin of western Svalbard (?20 to $9.5 \mathrm{Ma}$ ). Hence magmatic contamination (mafic/ultramafic intrusions), probably induced by convection partial melting (Mutter et al., 1988), seems possible. At extreme slow-spreading ridges such as Knipovich Ridge (0.8 cm/a, half rate; Eldholm et al., 1990), the melt fraction distribution can be lowered with depth (White et al., 2001). This might promote melt injection into the lower parts of the crust (15-25 km depth) off Van Mijenfjorden).

\section{Oceanic crust}

The western oceanic section ( $55 ;-50$ and $110 \mathrm{~km}$ ). Oceanic crust is surveyed along a $170 \mathrm{~km}$ long section on the seismic refraction profile. Despite a large re- ceiver spacing the seismic structure and the thickness variations along that section are, due to numerous $\mathrm{p}_{\mathrm{n}}$ phases, well constrained at least for the section east of Knipovich Ridge (see Figure 5a; station OBS14). Moreover, the calculated resolution (Figure 6) and the derived $\chi^{2}$-values (Table 1) allow a first detailed seismic interpretation of oceanic crust off Knipovich Ridge: The thickness of igneous crust varies between 1.5 and $4.0 \mathrm{~km}$. Lower thicknesses are associated with three $8-12 \mathrm{~km}$ wide crustal sections at $\mathrm{km}$ (i) -35 , (ii) 50 and (iii) 85 . Seismic reflection data of profile 7 (Figures 4 and 7, line drawing) supports the trend in Moho-topography between ii and iii. Sub-sedimentary reflections occur deeper ( $5 \mathrm{~s} \mathrm{twt}$ ) between the thinned crustal sections. The deeper reflections between CDP 5600 and 6000 (90-100 km; Figure 4) exhibit a thickness of up $0.5 \mathrm{~s}$ twt. The seismic velocities derived from wide-angle data within the oceanic crust off Knipovich Ridge range from 4.1 (4.3) to $4.7 \mathrm{~km} \mathrm{~s}^{-1}$. Hence, for a crustal thickness of $1.5 \mathrm{~km}$ a respective twt of $\sim 0.5 \mathrm{~s}$ is calculated. This implies that the lower reflections (Figure 4) are probably reflected off the Moho.

At the ridge seismic velocities decrease to 2.5 to $3.5 \mathrm{~km} \mathrm{~s}^{-1}$. Application of the inversion method of Zelt and Smith (1992) also derives low seismic velocities for mantle rocks underneath the thinned crustal sections at $\mathrm{km} 50$ and 85 (ii, iii). At minimum velocities of $7.3 \mathrm{~km} \mathrm{~s}^{-1}$ are calculated, compared to $8.2 \mathrm{~km} \mathrm{~s}^{-1}$ below oceanic crust with a thickness of 3.5 to $4 \mathrm{~km}$. Due to the marginal position of OBS16 $(\mathrm{km}-35)$ seismic velocities below section $\mathrm{i}$ are less constrained $\left(8.0 \mathrm{~km} \mathrm{~s}^{-1}\right)$.

At $\mathrm{km} 100$ reflection data (Figure 4) reveals a deepening crust-mantle boundary that might reflect a mismatch in our determination from velocity modelling.

The observed seismic velocities in oceanic crust indicate only the presence of oceanic layer 2 . P-wave velocities of layer 3 above the oceanic Moho are typically $>6.5 \mathrm{~km} \mathrm{~s}^{-1}$, and rarely exceed $7.2 \mathrm{~km} \mathrm{~s}^{-1}$ (White et al., 2001). The absence of oceanic layer 3 is typical for slow-spreading ridges with a half spreading rate below $2 \mathrm{~cm} / \mathrm{a}$ (White et al., 2001). According to Eldholm et al. (1990) a rate of $0.8 \mathrm{~cm} / \mathrm{a}$ is expected for the northern Knipovich Ridge. Conductive cooling of the slowly ascending mantle (White et al., 2001) is therefore supposed to decrease the melt fraction at Knipovich Ridge leading to lower magma supply for the creation of layer 3 . The proximity of cool contin- 


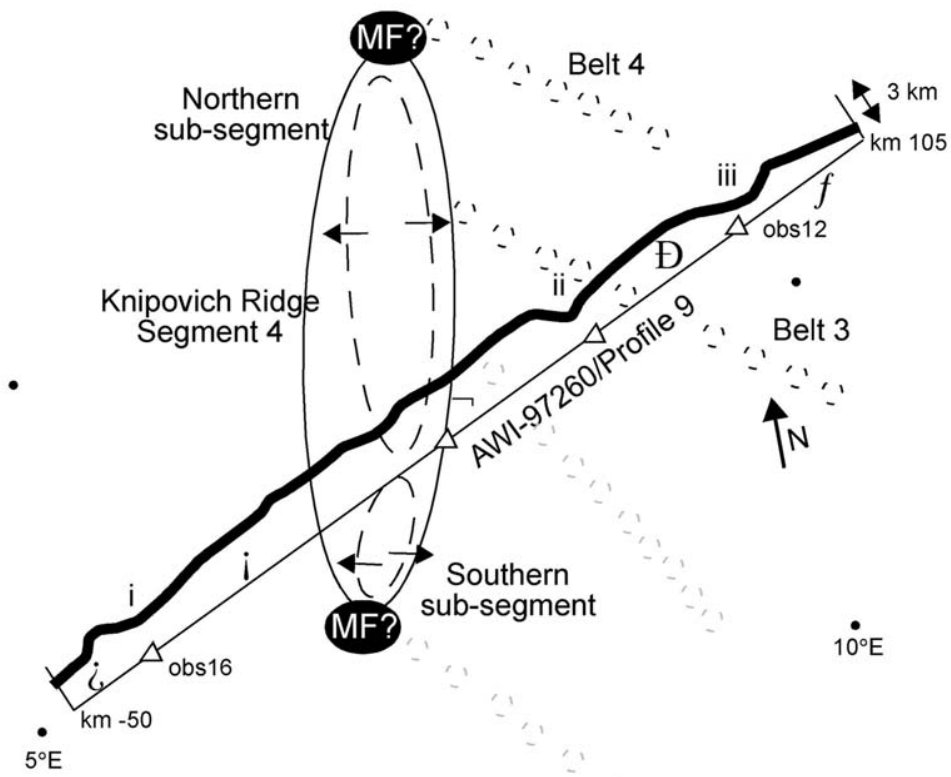

Figure 9. Schematic projection of oceanic crustal thickness and Knipovich Ridge segmentation. Oceanic crustal thickness (thick line in graph) along the seismic refraction transect (thin straight line) and Knipovich Ridge second order segment 4 (solid oval with two (third order) sub-segments, dashed ovals; after Crane et al., 2001). Sections i, ii and iii are the respective zones of thinned oceanic crust as used in the text. Thin black arrows indicate the spreading direction of the third order segments as inferred from fault orientation at the ridge. The chains of open circles show the track of observed seamount belts (gray: belt 1 and 2; black: belt 3 and 4; Crane et al., 1991). Magma focus points (MF) at the boundaries of the segment after Crane et al. (2001). White triangles indicate the positions of deployed obs receivers. Note, that the seamount belts 3 and 4 intersect the refraction transects at profile sections ii and iii.

ental crust adjoining the Spitsbergen Shear Zone might further enhance conductive heat loss at the ridge.

Following Crane et al.'s (2001) segmentation model of the Knipovich Ridge, the oceanic crust explored east of the ridge was formed at the second order segment $4\left(76^{\circ} 38^{\prime} \mathrm{N}\right.$ to $\left.77^{\circ} 25^{\prime} \mathrm{N}\right)$. The authors conclude that magma supply is focused at the segment ends (Figure 9) and argue therefore against models for magma accretion of e.g. Lin et al. (1990) in which buoyancy-driven mantle flow feeds the central positions of high order segments where maximum crustal thickness is achieved. Assuming the bounding discontinuities were always stationary, the segment boundaries project onto $\sim-10$ and $\sim 85 \mathrm{~km}$ (iii) on our profile, using the spreading direction vectors of Crane et al. (2001) based on DeMets et al. (1990). At these projection points the thickness of oceanic crust is not enhanced and magma supply is therefore probably not focused at the segment boundaries. Further it seems that the northern third-order sub-segment of segment 4 is itself segmented since we interpret the thinned crustal sections at 50 and $85 \mathrm{~km}$ (ii, iii) as fracture zones. The projection paths of these fracture zones correspond with observed seamount belts 3 and 4 (Crane et al., 2001). Low mantle velocities of $7.3 \mathrm{~km} \mathrm{~s}^{-1}$ below these zones of thinned crust may represent serpentinized peridotites, such as found on North Atlantic fracture zones (Detrick et al., 1993). We suppose roughly $20 \%$ serpentinization according to Christensen (1966) who determined seismic velocities of 7.2 to $7.3 \mathrm{~km} \mathrm{~s}^{-1}$ on such partially serpentinized peridotites. Summarising the discussion above we propose a different kind of magma distribution along Knipovich Ridge, since five crustal segments are observed along the transect (separated by i, ii, iii and the northern tip of the southern sub-segment see Figure 9; $\sim 0 \mathrm{~km}$ ). More recent analysis of bathymetric and bouguer anomaly data performed by Okino et al. (2002) confirm our observation and locate the loci of magma upwelling at the segment centers. The observed seamount belts (Crane et al., 2001) might have developed adjacent to the thin crust along the fracture zones, although it has to be considered that these belts may be outcrops of a fracture-parallel transverse ridge. 

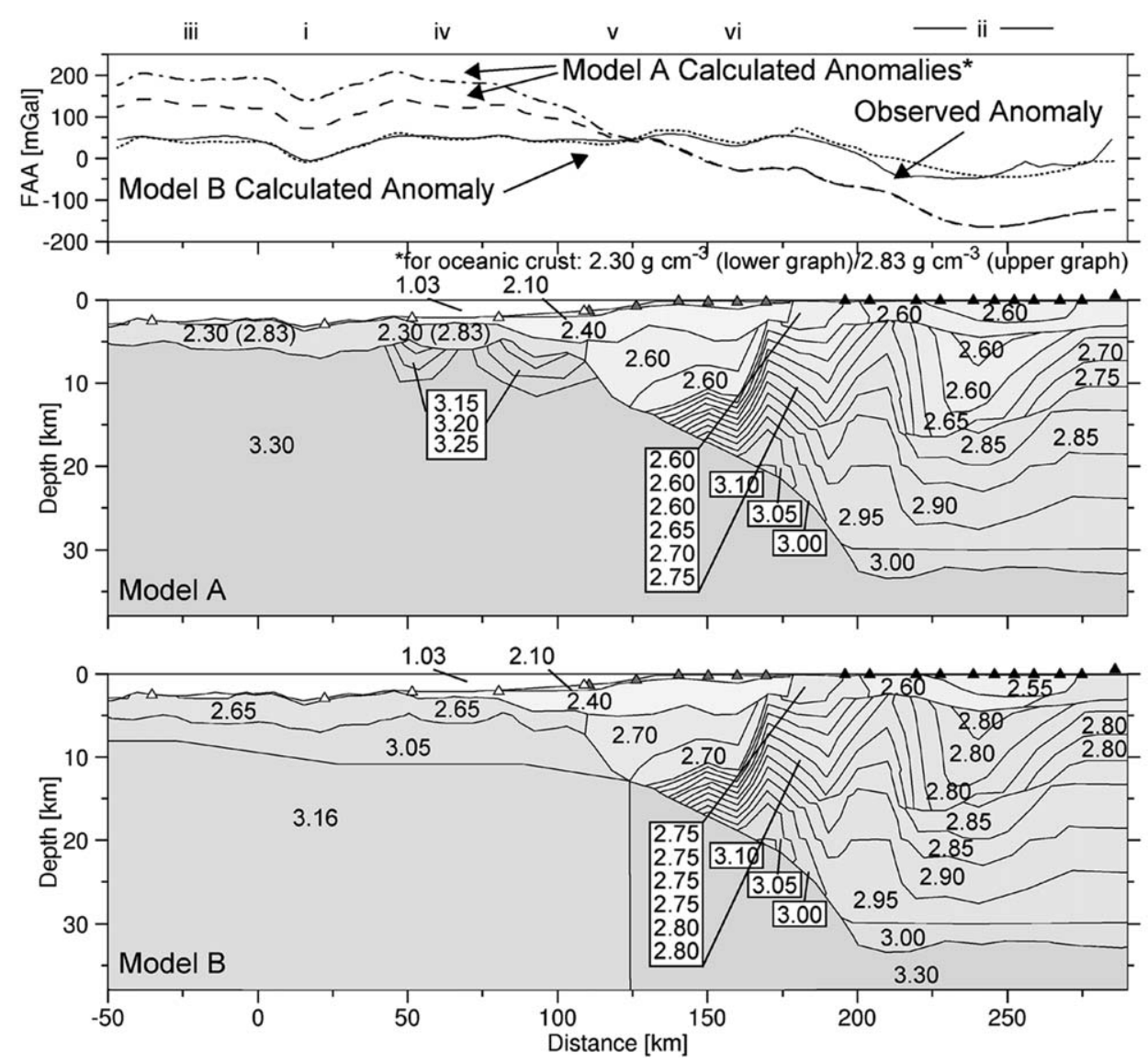

Figure 10. Initial (A) and final (B) density models and free-air anomaly for profiles AWI-97260 and profile 9. Initial (model A) and final (model B) density models for profile AWI-97260 and profile 9. Model A was twice-calculated with different densities for the oceanic crust, i.e. 2.3 and $2.83 \mathrm{~g} \mathrm{~cm}^{-3}$. The observed free-air anomaly is marked by a thick solid line in the upper graph. The calculated free-air anomalies from model A are marked by a long-dashed line $\left(\rho_{\text {oceanic }}=2.3 \mathrm{~g} \mathrm{~cm}^{-3}\right)$ and a dashed-dotted line $\left(\rho_{\text {oceanic }}=2.83 \mathrm{~g} \mathrm{~cm}^{-3}\right)$, from model B by a dotted line. For calculation of densities and modelling parameters see text. Triangles as for Figure 1.

\section{Modelling of the free-air gravity anomaly}

As a further element for interpretation and discussion of the observed crustal structure we modelled free-air gravity anomaly data. The deduced density structure along the profiles is intended to constrain the observed velocity structure using common velocity/density relationships. The modelled densities further provide additional rheologic properties.

Observed free-air anomaly. The observed free-air anomaly shows an overall variation of $\sim 105 \mathrm{mGal}$ (Figure 10). The most pronounced negative anomalies are observed at the Knipovich Ridge (i; $-55 \mathrm{mGal}$; Figure 10) and at the continent-ocean boundary (ii; $-100 \mathrm{mGal})$. The continental profile section along the Tertiary Central Spitsbergen Basin shows a mean level of $\sim 42 \mathrm{mGal}$ with an increasing trend east of
$250 \mathrm{~km}(\sim 0 \mathrm{mGal})$. The oceanic crust and the western continent-ocean transition (west of $190 \mathrm{~km}$ ) show a common level of approximately $+50 \mathrm{mGal}$ with some negative anomalies superimposed $(-5$ to $-20 \mathrm{mGal}$ amplitude) between (iii-vi) exhibiting a wavelength of 20 to $50 \mathrm{~km}$.

The initial density model. The observed velocity structure was transformed into an initial density model A (Figure 10): Over the continental crust the velocity model was digitized and converted to density bodies in $0.05 \mathrm{~g} \mathrm{~cm}^{-3}$ increments using the nonlinear velocity-density relationship of Christensen and Mooney (1995). The density for offshore sedimentary cover was set to 2.10 (uppermost) and $2.40 \mathrm{~g} \mathrm{~cm}^{-3}$. Densities typical for oceanic layer 2 vary between $<2.3$ (A), 2.62 to 2.69 (B) and $2.83 \mathrm{~g} \mathrm{~cm}^{-3}$ (C; 

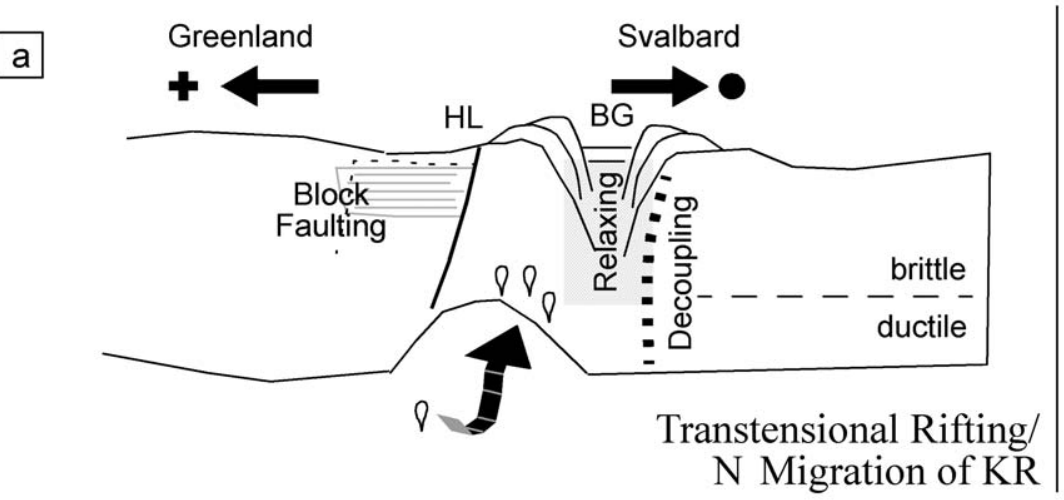

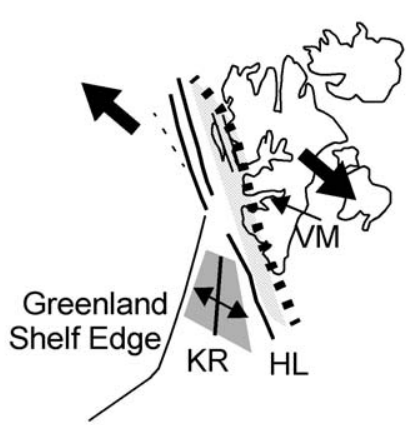

$\mathrm{b}$
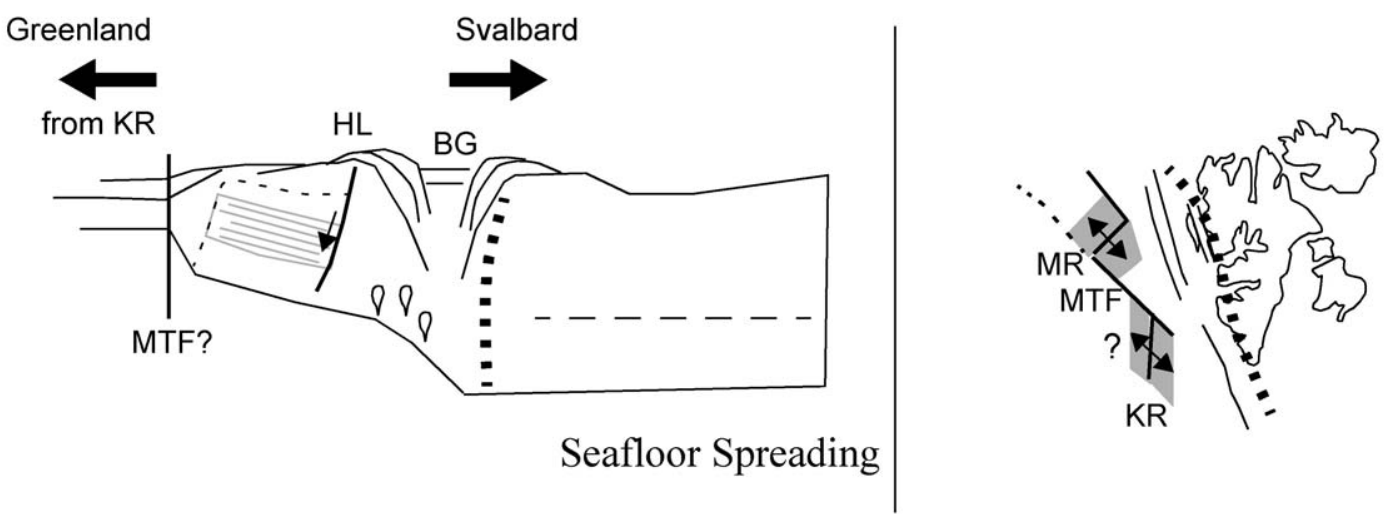

Figure 11. Schematic evolution of the continental margin off Van Mijenfjorden. Schematic evolution of the continental margin off Van Mijenfjorden (VM) derived from the interpretation of seismic refraction profiles AWI-97260 and profile 9. During the Paleocene a transpressional regime dominated between Svalbard and Greenland and resulted in the West Spitsbergen Fold Belt (cross hatch pattern). Since first subsidence of the Forlandsundet Graben is achieved during this phase we propose a similar history for the Bellsund Graben (BG) off Van Mijenfjorden. Intensive shearing weakened the upper brittle part of the crust. The vertical dotted line indicates approximately the boundary between the central and the western terrane. (a) Since Oligocene transtension occurred at the Hornsund Lineament (HL), the active fault system between Svalbard and Greenland. Stress was taken off the Fold Belt (Bellsund region), and thinning of the western terrane occurred decoupled from central Svalbard. West of the HL block faulting took place. Note that the upper crust is supposed to comprise Paleozoic to Mesozoic consolidated sedimentary rocks (gray box). The northern segment of the Knipovich Ridge (KR) was situated directly adjacent to the slightly thinned crust off Van Mijenfjorden. Mantle derived melts were injected into the lower crust at the central rift. Later (b) the mid-ocean ridge system migrated further north. Rifted crustal sections were tilted and buried below younger sediments.

Carlson and Herrick, 1990). According to the wide range of layer 2 densities two initial models were suggested: The first model shows oceanic crust with a unique (very low) density of $2.3 \mathrm{~g} \mathrm{~cm}^{-3}$ along the entire oceanic crustal section. The second model shows layer 2C-type densities for the entire oceanic crust $\left(2.83 \mathrm{~g} \mathrm{~cm}^{-3}\right)$. In zones of decreased seismic velocities below thinned oceanic crust, we assign a decreased density of $3.15 \mathrm{~g} \mathrm{~cm}^{-3}$, according to density determinations of Christensen (1966) on partially serpentinised peridotites $(22 \%)$. The residual mantle density was set to $3.3 \mathrm{~g} \mathrm{~cm}^{-3}$.

The long-wavelength variation of the calculated free-air anomaly of model A is more than $300 \mathrm{mGal}$, regardless of the chosen oceanic crustal density (Figure 10). This is more than three times higher than observed. Low oceanic crustal densities result in a lower long-wavelength anomaly on the oceanic crustal section (approximately $50 \mathrm{mGal}$ lower compared to the high density model). A positive deviation along the oceanic profile (100 to $150 \mathrm{mGal}$ west of $140 \mathrm{~km}$ ) and a negative deviation on the transitional and continental section (70 to $100 \mathrm{mGal}$ east of $140 \mathrm{~km}$ ) is achieved. Nevertheless short wavelength anomalies (such as i, ii or vi) are well matched.

The final density model. The following changes were applied to provide a better fitting free-air anomaly 
model (model B, Figure 10):

(1) In order to increase the anomaly on the eastern continental section the densities within the upper and middle crust had to be increased by about 0.05 to 0.2 $\mathrm{g} \mathrm{cm}^{-3}$. Densities for the Tertiary Central Spitsbergen Basin were lowered to more reasonable values $\left(2.55 \mathrm{~g} \mathrm{~cm}^{-3}\right)$. The high densities within the upper crystalline crust are consistent with densities up to $2.8 \mathrm{~g} \mathrm{~cm}^{-3}$ measured on Svalbard rock samples by Kurinin (1970) and Howells et al. (1977). Densities of $2.70 \mathrm{~g} \mathrm{~cm}^{-3}$ are inferred for depths of 5 to $15 \mathrm{~km}$ west of the Hornsund Lineament where Paleozoic or Mesozoic sedimentary rocks are expected from the velocity structure. Kurinin (1970) and Howells et al. (1977) measured similar group densities on rock samples of such sedimentary rocks.

(2) According to the density variations observed in oceanic layer 2 (Carlson and Herrick, 1990) a mean density of $2.65 \mathrm{~g} \mathrm{~cm}^{-3}$ (layer 2B-type) was chosen for the oceanic crustal layer of the final model. To match the free-air anomaly along this crustal section, the mantle density was generally decreased to $3.05 \mathrm{~g} \mathrm{~cm}^{-3}$ down to depths of $\sim 10 \mathrm{~km}$. This level roughly marks the depth where low mantle velocities of $7.5 \mathrm{~km} \mathrm{~s}^{-1}$ are replaced by higher velocities of $8.1 \mathrm{~km} \mathrm{~s}^{-1}$ at the continent-ocean transition (Figure 7). The density of the deeper mantle of model B is also decreased $\left(3.16 \mathrm{~g} \mathrm{~cm}^{-3}\right)$. We suggest thus that the oceanic mantle may be generally serpentinized (20 to $30 \%$; Christensen, 1966) along the entire oceanic crustal section ( $\mathrm{km}-50$ to 110$)$.

Evaluation of density modelling. Breivik et al. (1998) report a similar extreme mismatch between the observed free-air anomaly and the inferred anomaly from seismic crustal models off Senja Margin and the Svalbard Platform. The mismatch along the oceanic profile section amounts up to $200 \mathrm{mGal}$ with a gradual increasing deviation west of the continentocean boundary. Breivik et al. (1998) simulate the complex temperature development at the margin transects to derive the thermal structure of the upper mantle to a depth of $125 \mathrm{~km}$. After converting mantle temperature to density and subsequent calculation of the free-air anomaly an improved fit was achieved along the oceanic profile section. The derived densities of the upper mantle $100 \mathrm{~km}$ off the (sheared) continental margin are 3.16 (sub-crustal) to $\times 3.26 \mathrm{~g} \mathrm{~cm}^{-3}$ (125 km depth).

With reference to this we conclude that our gravity modelling only provides a reasonable structure along the eastern continental section. For the oceanic section model B can be merely regarded as a simple approximation (Figure 10), since a detailed mantle structure is missing. Further research has to be carried out, the solution may be given by simple thermal modelling of the upper mantle as done by Breivik et al. (1998).

\section{The development of the continental margin off Van Mijenfjorden}

The velocity structure of the continental margin off Van Mijenfjorden can be used for a simple schematic Cenozoic evolution model, since it reveals information about the West Spitsbergen Orogeny as well as the rifting procedure in Oligocene.

The Spitsbergen Orogeny was a Late Paleocene transpressive event (Steel et al., 1985; Eldholm et al. 1987). According to our observations along the seismic refraction profile we characterise the deeper roots of the fold belt as intensively faulted rocks, that are most probably related to oblique convergent wrenching. This gave way to transtension since the Oligocene (Eldholm et al., 1987) and the intensively faulted rock units entered a relaxing phase (Figure 11a). Crustal thinning occurred but is limited to the Caledonian western terrane of Svalbard. The profile reveals that crustal thinning is decoupled from inner Svalbard (the central terrane), probably the consequence of the former transpressive suture of the West Spitsbergen Fold Belt, that itself is located in close proximity to the Caledonian suture.

The main fault zone between Svalbard and Greenland was most probably the Hornsund Lineament (Eiken, 1993) that is supposed to bound a Paleozoic (Carboniferous?) or Mesozoic sedimentary basin to the east (e.g., Mann and Townsend, 1989; Townsend and Mann, 1989). The Knipovich Ridge is supposed to have been located adjacent to Van Mijenfjorden during the Miocene (Crane et al., 1991; Boebel, 2000). Elevated lower crustal velocities are found at the continent-ocean transition and we suppose magmatic interaction between the deeper mid-oceanic ridge and the continental crust, keeping in mind that a riftedvolcanic evolution can be excluded (Ritzmann and Jokat, 2003). As the mid-ocean ridge system migrated further north of the Knipovich Ridge (Figure 11b) opening of the Fram Strait, continental crust off Van Mijenfjorden was further thinned, rifted and probably block-faulted (Eiken and Austegard, 1987). The Hornsund Lineament developed. It remains unclear 
if the Molloy Transform Fault developed prior to the northern Knipovich Ridge leading to a sheared margin in the outer zone of the continent-ocean transition (km 110).

\section{Conclusions}

The main results of our study are:

(1) Cenozoic sediments and sedimentary rocks on- and offshore exhibit seismic velocities from 4.5 to $5.4 \mathrm{~km}$ $\mathrm{s}^{-1}$ (Spitsbergen Tertiary Basin, onshore) and 1.7 and $3.9 \mathrm{~km} \mathrm{~s}^{-1}$ (offshore) with maximum thicknesses of 3.5 and $5 \mathrm{~km}$, respectively. Below the Cenozoic cover onshore are up to $8 \mathrm{~km}$ of Devonian rocks associated with the Nordfjorden Block. West of the Hornsund Lineament the velocity structure gives rise to the suspicion that Paleozoic sedimentary strata occur below the Cenozoic cover.

(2) The western and central Caledonian terranes can be differentiated, the boundary occurs at the western termination of the Devonian deposits on the Nordfjorden Block. Seismic velocities range from $5.4 \mathrm{~km} \mathrm{~s}^{-1}$ at the top ( $\mathrm{W}^{\prime}$ Akseløya) to $6.8 \mathrm{~km} \mathrm{~s}^{-1}$ at the Moho. The upper and middle crust at the West Spitsbergen Fold Belt reveals decreased seismic velocities that are interpreted as an intensively faulted rock construction due to transpressive movements during the West Spitsbergen Orogeny. The lower parts of the rifted crust show a small zone of slightly elevated velocities $(7.2 \mathrm{~km}$ $\mathrm{s}^{-1}$ ). These are interpreted as mantle-derived mafic or ultramafic rocks. Melts were possibly channelled from distant sources by the Spitsbergen Shear Zone, or intruded while the northern Knipovich Ridge was adjacent to the young rift off Van Mijenfjorden.

(3) The oceanic crust related to the Knipovich Ridge shows maximum thicknesses of $4.0 \mathrm{~km}$. The seismic velocities observed within oceanic crust indicate the absence of layer 3 (3.5/4.1 to $\left.4.7 \mathrm{~km} \mathrm{~s}^{-1}\right)$. Minimum thicknesses of 1 to $2 \mathrm{~km}$ are achieved in narrow zones, interpreted as fracture zones. Below these fractures the seismic velocity of the upper mantle is low $(7.3 \mathrm{~km}$ $\mathrm{s}^{-1}$ ) leading to the assumption that the mantle is partly serpentinized. The distribution of fracture zones and thicker crustal sections (30 to $50 \mathrm{~km}$ spacing) give new constraints on the segmentation of the northern Knipovich Ridge.

(4) Density modelling along the seismic refraction transect confirms the observed velocity structure for the continental and transitional crustal sections. We assume an extreme mismatch of up to $150 \mathrm{mgal}$ along the oceanic profile section is due to a more complex density (i.e., thermal) structure of the upper mantle.

\section{Acknowledgements}

We gratefully thank the crew and scientific staff of RV Polarstern (Cruise ARK 13/3), RV Håkon Mosby (OBS98) and RV Håkon Mosby ('99-survey).

\section{References}

Amundsen, H.E.F., Griffin, W.L. and O'Reilly, S.Y., 1987, The lower crust and upper mantle beneath northwestern Spitsbergen: evidence from xenoliths and geophysics, Tectonophysics $\mathbf{1 3 9}$, $169-185$.

Boebel, T., 2000, Airborne topography and gravimetry: System and application to Fram Strait, Svalbard and Northeast Greenland, Reports on Polar and Marine Research 366.

Breivik, A.J., Faleide, J.I. and Verhoef, J, 1998, Effect of thermal contrasts on gravity modeling at passive margins; results from the western Barents Sea, J. Geophys. Res. 104 (7), 15.29315.311.

Carlson, R.L. and Herrick, C.N., 1990, Densities and porosities in the oceanic crust and their variations with depth and age, $J$. Geophys. Res. 95 (B6), 9153-9170.

Chan, W.W. and Mitchell, B.J., 1982, Synthetic seismogram and surface wave constrains on crustal models of Spitsbergen, Tectonophysics 89, 51-76.

Christensen, N.I., 1966, The elasticity of ultrabasic rocks, J. Geophys. Res. 71, 5921-5931.

Christensen, N.I. and Mooney, W.D., 1995, Seismic velocity structure and composition of the continental crust: A global view, $J$. Geophys. Res. 100 (B7), 9761-9788.

Crane, K., Sundvor, E., Buck, R. and Martinez, F., 1991, Rifting in the Northern Norwegian-Greenland sea: Thermal Tests of Asymmetric Spreading, J. Geophys. Res. 96 (B9), 14529-14550.

Crane, K., Doss, H., Vogt, P., Sundvor, E., Cherkashov, G., Poroshima, I. and Joseph, D., 2001, The role of the Spitsbergen shear zone in determining morphology, segmentation and evolution of the Knipovich Ridge, Mar. Geophys. Res. 22: 153-205.

Czuba, W., Grad, M. and Guterch, A., 1999, Crustal structure of north-western Spitsbergen from DSS measurements, Polish Pol. Res. 20 (2), 131-148.

DeMets, C., Gordon, R.G., Argus, D.F. and Stein, S., 1990, Current plate motions, Geophys. J. Int. 101, 425-478.

Detrick, R.S., White, R.S. and Purdy, G.M., 1993, Crustal structure of North Atlantic Fracture Zones, Rev. Geophys. 31 (4), 439-458.

Eiken, O., 1993, An outline of the northwestern Svalbard continental margin, in Arctic Petroleum Potential, in: Vorren, T.O., Bergsager, E., Dahl-Stamnes, Ø.A., Holter, E., Johansen, B., Lie, E. and Lund, T.B. (Eds.), Arctic Geology and Petroleum Potential, NPF Special Publication 2, Elsevier, Amsterdam, pp. 619-629.

Eiken, O., 1994, Seismic Atlas of Western Svalbard - A selection of regional seismic transects, Norsk Polarinstitutt Meddelelser 130, 3-73.

Eiken, O. and Austegard, A., 1987, The Tertiary orogenic belt of West-Spitsbergen: Seismic expressions of the offshore sedimentary basins, Norsk Geologisk Tidsskrift 67, 383-394. 
Eldholm, O., Faleide, J., I. and Myhre, A.M., 1987, Continentocean transition at the western Barents Sea/Svalbard continental margin, Geology 15, 1118-1122.

Eldholm, O., Karasik, A.M. and Reksnes, P.A., 1990, The North American plate boundary, in: Grantz, A., Johnson, L. \& Sweeney, J.F. (Eds.), The Arctic Ocean region. The Geology of North America L, Geological Society of America, Boulder, Colorado, pp. 171-184.

Faleide, J.I., Gudlaugsson, S.T., Eldholm, O., Myhre, A.M. and Jackson, H.R., 1991, Deep seismic transects across the sheared western Barents Sea-Svalbard continental margin, Tectonophysics 189, 73-89.

Faleide, J.I, Vågnes, E. and Gudlaugsson, S.T., 1993, LateMesozois-Cenozoic evolution of the south-western Barents Sea in a regional rift-shear tectonic setting, Mar. Pet. Geol. 10, 186-214.

Feden, R. H., Vogt, P.R. and Fleming, H.S, 1979, Magnetic and Bathymetric Evidence for the "Yermak Hot Spot" northwest of Svalbard in the Arctic Basin, Earth Planet. Sci. Lett. 44, 18-38.

Gabrielsen, R. H., Oddbjørn, S.K., Haugsbø, H., Midbøe, P.S., Nøttvedt, A., Rasmussen, E. and Skott, P.H., 1992, A structural outline of Forlandsundet Graben, Prins Karls Forland, Svalbard, Norsk Geologisk Tidsskrift 72, 105-120.

Guterch, A., Pajchel, J., Perchuc, E., Kowalski, J., Duda, S., Komber, G., Bojdys and G., Sellevoll, M.A., 1978, Seismic reconnaissance measurements on the crustal structure in the Spitsbergen Region 1976, University of Bergen Seismological Observatory, Bergen.

Hajnal, Z., Burianyk, M.J.A., Kesmarky, I. and Overton, A., 1990, Reflection Survey on Hobson's Choise Island, Arctic Ocean, Mar. Geol. 93, 211-224.

Harland, W.B. and Wright, N.J.R., 1979, Alternative hypothesis for the pre-Carboniferous evolution of Svalbard, Norsk Polarinstitutt Skrifter 167, 89-117.

Harland, W.B., 1997a, Svalbard's geological frame, in Harland, W.B. (ed.), The Geology of Svalbard, Geol. Surv. Mem. 17, The Geological Society London, UK, pp. 23-44.

Harland, W.B., 1997b, Devonian History, in Harland, W.B. (ed.), The Geology of Svalbard, Geol. Surv. Mem. 17, The Geological Society London, UK, pp. 289-309,

Harland, W.B., 1997c, Central Western Spitsbergen (with a contribution with Geddes, I. and Doubleday, P.A.), in Harland, W.B. (Ed.), The Geology of Svalbard, Geol. Surv. Mem. 17, The Geological Society London, UK, pp. 154-178.

Harland, W.B., 1997d, Paleogene History (with a contribution with Challinor, A. and Doubleday, P.A.), in: Harland, W.B. (ed.), The Geology of Svalbard, Geological Survey Memoir 17, The Geological Society London, UK, pp. 388-417.

Howells, K., Masson Smith, D. and Maton, P.I., 1977, Some rock and formation densities from Svalbard, Årbok Norsk Polarinstitutt 1975, 53-67.

Jakobsson, M., Cherkis, N.Z., Woodward, J., Macnab, R. and Coakley, 2000, New grid of Arctic bathymetry aids scientists and mapmakers, EOS Transactions $\mathbf{8 1}$ (9), 89, 93, 96.

Jackson, H.R., 1990, Evolution and Regional Stratigraphy of the Northeastern Canadian Polar Margin, Mar. Geol. 93, 179-192.

Jackson, H.R., Johnson, G.L., Sundvor, E. and Myhre, A., 1984, The Yermak Plateau: Formed at a Triple Junction, J. Geophys Res. 89 (B5), 3223-3232.

Johannessen, E.P. and Steel, R.J., 1992, Mid-Carboniferous extension and rift-infill sequences in the Billefjorden Trough, Svalbard, Norsk Geologisk Tidsskrift 72, 35-48.

Jokat, W., Eisen, O., Konn, B., Lensch, N., Martens, H., Ritzmann, O., Rogenhagen, J., Thalmann, K. and Weigelt, E., 1998, Marine
Geophysics, in: Krause, G. (ed.), The Expedition ARKTISXIII/3 of RV 'Polarstern' in 1997, Reports on Polar and Marine Research 262, Alfred Wegener Institute for Polar and Marine Research, Bremerhaven, pp. 71-82.

Kellogg, H.E., 1975, Tertiary Stratigraphy and Tectonism in Svalbard and Continental Drift, AAPG Bull. 59 (3), 465-485.

Kurinin, R.G., 1970, Density and Magnetic Suscpetibilities of Spitsbergen Rocks, in Harland, W.B. (ed.), Geology of Spitsbergen (1965) Vol. 2, National Lending Library for Science and Technology, Yorshire, UK, pp. 284-286.

Lin, J., Purdy, G.M., Schouten, H., Sempere, J.-C. and Zervas, C., 1990, Evidence from gravity data for focused magmatic accretion along the Mid-Atlantic Ridge, Nature 344, 627-632.

Lowell, J.D., 1972, Spitsbergen Tertiary Orogenic Belt and the Spitsbergen Fracture Zone, Geol. Soc. Am. Bul. 83, 3091-3102.

Manby, G. and Lyberis, N., 1992, Tectonic evolution of the Devonian Basin of northern Svalbard, in: Dallmann, W.K., Andresen, A. \& Krill, A. (eds.), Post-Caledonian Tectonic Evolution of Svalbard, Norsk Geologisk Tidskrift 72, 7-19.

Mann, A. and Townsend, C., 1989, The post-Devonian tectonic evolution of southern Spitsbergen illustrated by structural crosssections through Bellsund and Hornsund, Geological Magazine 126, 549-566.

Mjelde, R., Van Schaak, M. and Shimamura, H., 1998, OBS experiment in the Northern Barents Sea, 11. July-31. August, 1998, Cruise report, University of Bergen, Bergen.

Mjelde, R. and Johansen, T.A., 1999, Cruise Report: Multichannel reflection survey west Spitsbergen, 17 September-1 October 1999, Cruise report, University of Bergen, Bergen.

Müller, D. and Spielhagen, R.F., 1990, Evolution of the Central Tertiary Basin of Spitsbergen: towards a synthesis of sediment and plate tectonic history, Palaeogeogr., Palaeoclimatol. Palaeoecol. 80, 153-172.

Mutter, J.C., Buck, W.R. and Zehnder, C.M., 1988, Convective partial melting. A model for the formation of thick basaltic sequences during the initation of spreading, J. Geophys. Res. 93 (B2), 1031-1048.

Myhre, A.M., Eldholm, O. and Sundvor, E., 1982, The margin between Senja and Spitsbergen fracture zones: Implications from plate tectonics, Tectonophysics $\mathbf{8 9}, 1-32$.

Myhre, A. M. and Eldholm, O., 1988, The Western Svalbard margin $\left(74^{\circ}-80^{\circ} \mathrm{N}\right)$, Mar. Petrol. Geol. 5, 143-156.

Nøttvedt, A., Livbjerg, F., Midbøe, P.S. and Rasmussen, E., 1993, Hydrocarbon potential of the Central Spitsbergen Basin, in: Vorren, T.O., Bergsager, E., Dahl-Stamnes, Ø.A., Holter, E., Johansen, B., Lie, E. and Lund, T.B. (eds.), NPF Special Publications 2, Elsevier, Amsterdam, pp. 333-361.

Okino, K., Curewitz, D., Asada, M., Tamaki, K., Vogt, P. and Crane, K., 2002, Preliminary analysis of the Knipovich Ridge segmentation: influence of focused magmatism and ridge obliquity on an ultraslow spreading system, E. Planet. Sci. Lett. 202, 275-288.

Posewang, J. and Mienert, J., 1999, High-resolution seismic studies of gas hydrates west of Svalbard, Geo-Mar. Let. 19, 150-156.

Ritzmann, O. and Jokat, W., 2003, Crustal structure of northwestern Svalbard and the adjacent Yermak Plateau: Evidence for Oligocene detachment tectonics and non-volcanic break-up, Geophys. J. Int. 152, 139-159.

Schlüter, H.U. and Hinz, K., 1978, The continental margin of West Spitsbergen. Polarforschung 48 (1/2), 151-169.

Sellevoll, M.A., Duda, S.J., Guterch, A., Pajchel, J., Perchus, E. and Thyssen, F., 1991, Crustal structure in the Svalbard region from seismic measurements, Tectonophysics 189, 55-71.

Steel, R.J., Helland-Hansen, W., Kleinspehn, K., Nøttvedt, A. and Rye-Larsen, M., 1985, The Teriary strike-slip basins and oro- 
genic belt of Spitsbergen, in: Biddle, K.T. and Christie-Blick, N., (Eds.), Strike-slip deformation, Basin formation and Sedimentation, Special Publications Society of Economic Paleontologists and Mineralogists 37, pp. 339-359.

Sundvor, E. and Austegard A., 1990, The Evolution of the Svalbard Margins: Synthesis and new Results, in Bleil, U. and Thiede, J. (eds.), Geological History of the Polar Oceans: Arctic Versus Antarctic, Kluwer Academic Publishers, Netherlands, pp. 77-94.

Thompson, R.N. and Gibson, S.A., 1991, Subcontinental mantle plumes, hotspots and pre-existing thinspots, J. Geol. Soc. London 147, 973-977.

Townsend, C. and Mann, A., 1989, The Tertiary Orogenic Belt of West Spitsbergen: seismic expressions of offshore sedimentary basins. A comment, Norsk Geologisk Tidskrift 69, 135-136.
White, R.S. and McKenzie, D., 1989, Magmatism at Rift Zones: The Generation of Volcanic Continental Margins and Flood Basalts, J. Geophys. Res. 94 (B6), 7685-7729.

White, R.S. and McKenzie, D., 1995, Mantle plumes and flood basalts, J. Geophys. Res. 100 (B9), 17543-17585.

White, R.S., Minshull, T.A., Bickle, M.J. and Robinson, C.J., 2001, Melt generation at very slow-spreading oceanic ridges; constraint from geochemical and geophysical data. J. Petr. 42 (6), 11711196.

Zelt, C.A. and Smith, R.B., 1992. Seismic travel time inversion for 2-D crustal velocity structure. Geophys. J. Int. 108, 16-34. 